Supporting Information

\title{
Molecular-Level Understanding of Excited States of N-Annulated Rylene Dye for Dye-Sensitized Solar Cells
}

Changwon Kim, ${ }^{\text {ab }}$ Tae Wu Kim, ${ }^{\text {b\# }}$ Siin Kim, ${ }^{\text {ab }}$ Inhwan Oh, ${ }^{\text {ab }}$ Henrike Wonneberger, ${ }^{\mathrm{c}}$ Kihwan Yoon, ${ }^{\text {d }}$ Minseok Kwak, ${ }^{\mathrm{e}}$ Joonghan Kim, ${ }^{\mathrm{d}}$ Jeongho Kim, ${ }^{\mathrm{f}}$ Chen Li, ${ }^{\mathrm{g}}$ Klaus Müllen, ${ }^{\mathrm{h}}$ and Hyotcherl Ihee ${ }^{* a b}$

${ }^{a}$ Department of Chemistry and KI for the BioCentury, Korea Advanced Institute of Science and Technology (KAIST), Daejeon 34141, Republic of Korea

${ }^{b}$ Center for Nanomaterials and Chemical Reactions, Institute for Basic Science (IBS), Daejeon 34141, Republic of Korea

${ }^{c}$ BASF SE, Carl-Bosch-Strasse 38, Ludwigshafen 67056, Germany

${ }^{d}$ Department of Chemistry, The Catholic University of Korea, Bucheon 14662, Republic of Korea

${ }^{e}$ Department of Chemistry, Pukyong National University, Busan 48513, Republic of Korea

${ }^{f}$ Department of Chemistry, Inha University, Incheon 22212, Republic of Korea

${ }^{g}$ School of Environment and Civil Engineering, Dongguan University of Technology, Dongguan, Guangdong Province, P. R. China

${ }^{h}$ Max Planck Institute for Polymer Research, Ackermannweg 10, 55128 Mainz, Germany

\#Present address: Chemical Sciences and Engineering Division, Argonne National Laboratory, Lemont, Illinois 60439, United States 


\section{Supporting Information (SI) Figures and Tables}

\section{Table of Contents}

Supplementary Note 1. Synthesis and characterization of DND

Supplementary Note 2. Steady-state spectroscopic data and the fluorescence lifetime

Supplementary Note 3. Details on DFT and TDDFT results

Supplementary Note 4. Broadband transient absorption experiments and data analysis

Supplementary Note 5. Photovoltaic performance of DND

SI Tables and Figures

Supplementary Note 6. Cartesian coordinates of optimized geometries of DND

SI References 


\section{Supplementary Note 1. Synthesis and characterization of DND}

\section{N-Cyclohexyl-4-(4-chloro-2-nitro-phenyl)-1,8-naphthalene dicarboximide}

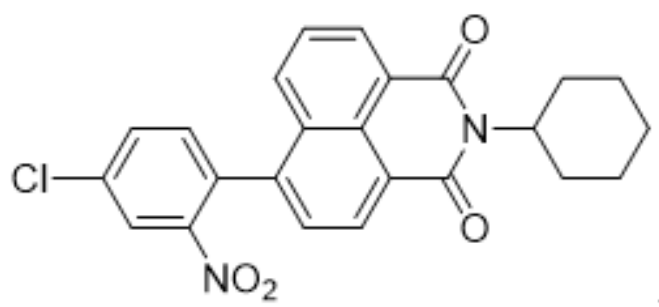

$2 \mathrm{~g}$ of N-cyclohexyl-4-(4,4,5,5-tetramethyl-1,3,2-dioxaborolane-2-yl)-naphthalene-1,8-dicarboximide $(4.93 \mathrm{mmol})$ and $1.75 \mathrm{~g}$ of 1-bromo-4-chloro-2-nitrobenzene $(7.40 \mathrm{mmol})$ were dissolved in $80 \mathrm{~mL}$ of toluene. $1.6 \mathrm{~g}$ of potassium carbonate $(11.6 \mathrm{mmol})$ dissolved in $8 \mathrm{~mL}$ of water, and $0.8 \mathrm{~mL}$ of ethanol were added. The solution was purged with argon for 30 minutes. After addition of $800 \mathrm{mg}$ tetrakis(triphenylphosphine)palladium(0) $(0.717 \mathrm{mmol})$, the solution was again purged for 30 minutes with argon. The solution was stirred at $80{ }^{\circ} \mathrm{C}$ for $60 \mathrm{~h}$. The reaction mixture was cooled down, washed with water, and extracted with dichloromethane. The reaction mixture was purified via column chromatography on silica gel with dichloromethane:petrol ether (1:1). Yield: $700 \mathrm{mg}$ light-yellow solid $(32 \%)$

${ }^{1}$ H-NMR (700 MHz, CD $\mathbf{C l}_{2}, 298$ K): $\delta$ [ppm]: 8.60 - $8.55(\mathrm{~m}, 2 \mathrm{H}), 8.23(\mathrm{~d}, \mathrm{~J}=2.1,1 \mathrm{H}), 7.79(\mathrm{dd}, \mathrm{J}=$ 2.1, 8.2, 1H), 7.74(dd, J = 0.9, 8.4, 1H), $7.70-7.66(\mathrm{~m}, 1 \mathrm{H}), 7.59(\mathrm{~d}, \mathrm{~J}=7.4,1 \mathrm{H}), 7.46(\mathrm{~d}, \mathrm{~J}=8.2,1 \mathrm{H})$, $5.05-4.97(\mathrm{~m}, 1 \mathrm{H}), 2.54(\mathrm{qd}, \mathrm{J}=3.5,12.5,2 \mathrm{H}), 1.90(\mathrm{~d}, \mathrm{~J}=13.2,2 \mathrm{H}), 1.78-1.69(\mathrm{~m}, 3 \mathrm{H}), 1.51-1.41$ (m, 2H), $1.38-1.28(\mathrm{~m}, 1 \mathrm{H})$.

${ }^{13}$ C-NMR (176 MHz, $\mathbf{C D}_{2} \mathrm{Cl}_{2}, 298$ K): $\delta[\mathrm{ppm}]: 164.8,164.6,149.8,141.4,136.2,134.4,134.1,132.7$, $131.5,130.9,130.7,130.4,128.8,128.1,127.5,125.6,124.5,124.3,29.7,27.2,26.1$. IR spectrum (ATR): $V_{\max }\left[\mathrm{cm}^{-1}\right]=3098,2928,2848,1701,1658,1594,1525,1389,1346,1231,1107,786$. UV-Vis spectrum $\left(\mathbf{C H}_{2} \mathbf{C l}_{2}\right): \lambda_{\max }[\mathrm{nm}]\left(\varepsilon\left[\mathrm{M}^{-1} \mathrm{~cm}^{-1}\right]\right)=340$ (16,888). High Resolution Mass (ESI): $[\mathrm{M}+\mathrm{H}]^{+}$: calculated: 435.1112, found: 435.1111, discrepancy: $-0.1 \mathrm{ppm}$. 


\section{N-Cyclohexyl-4-(4-bis(p-2,4,4-trimethylpentane-2-yl-phenyl)amino-2-nitro-phenyl)-1,8-}

naphthalene dicarboximide

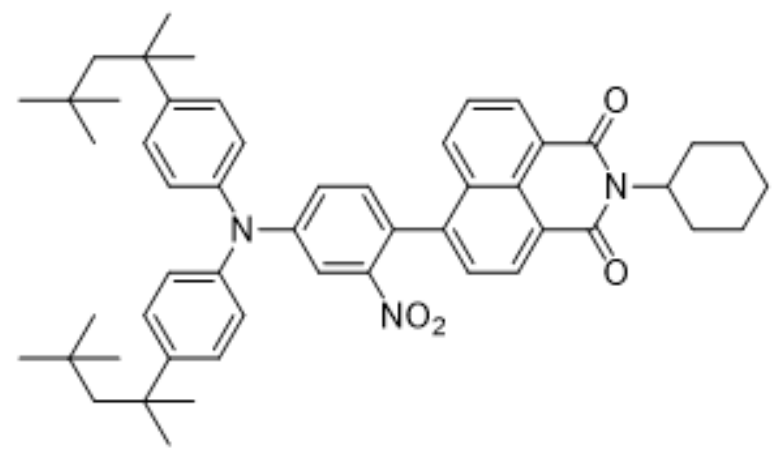

$600 \mathrm{mg}$ of N-cyclohexyl-4-(4-chloro-2-nitro-phenyl)-naphthalene-1,8-dicarboximide (1.38 mmol), 815 $\mathrm{mg}$ of bis(p-2,4,4-trimethylpentane-2-yl-phenyl)amine ( $2.07 \mathrm{mmol}), 900 \mathrm{mg}$ of caesium carbonate (2.76 $\mathrm{mmol}), 125 \mathrm{mg}$ of tris(dibenzylideneacetone) dipalladium(0) $(0.136 \mathrm{mmol})$, and $170 \mathrm{mg}$ of 2,2'bis(diphenylphosphino)-1,1'-binaphthyl $(0.273 \mathrm{mmol})$ were dissolved in $30 \mathrm{~mL}$ of anhydrous toluene in a Schlenk tube and stirred under argon at $100{ }^{\circ} \mathrm{C}$ for $16 \mathrm{~h}$. The reaction mixture was purified via column chromatography with dichloromethane:petrol ether (1:1). Yield: $640 \mathrm{mg}$ yellow solid (64\%)

${ }^{1} \mathbf{H}-N M R\left(700 \mathrm{MHz}, \mathbf{C D}_{\mathbf{2}} \mathbf{C l}_{\mathbf{2}}, \mathbf{2 9 8} \mathbf{~ K}\right): \delta[\mathrm{ppm}]: 8.55(\mathrm{~d}, \mathrm{~J}=7.5,2 \mathrm{H}), 7.93(\mathrm{~d}, \mathrm{~J}=8.4,1 \mathrm{H}), 7.71-7.66$ (m, 1H), $7.62-7.58(\mathrm{~m}, 2 \mathrm{H}), 7.41(\mathrm{~d}, \mathrm{~J}=8.7,4 \mathrm{H}), 7.27(\mathrm{dd}, \mathrm{J}=2.5,8.5,1 \mathrm{H}), 7.21(\mathrm{~d}, \mathrm{~J}=8.5,1 \mathrm{H}), 7.17$ $(\mathrm{d}, \mathrm{J}=8.6,4 \mathrm{H}), 5.07-4.95(\mathrm{~m}, 1 \mathrm{H}), 2.60-2.48(\mathrm{~m}, 2 \mathrm{H}), 1.89(\mathrm{~d}, \mathrm{~J}=13.2,2 \mathrm{H}), 1.80-1.68(\mathrm{~m}, 7 \mathrm{H}), 1.51$ - 1.23 (m, 15H), 0.76 (s, 18H). ${ }^{13} \mathbf{C}-\mathbf{N M R}\left(\mathbf{1 7 6} \mathbf{~ M H z}, \mathbf{C D}_{\mathbf{2}} \mathbf{C l}_{\mathbf{2}}, \mathbf{2 9 8} \mathbf{~ K}\right): \delta[\mathrm{ppm}]: 165.0,164.8,150.3,147.9$, 143.7, 143.3, 133.4, 131.5, 131.3, 130.9, 128.8,128.4, 127.7, 125.8, 124.4, 124.2, 123.6, 123.5, 115.1, 57.6, 38.9, 32.9, 32.0, 31.8, 29.7,27.2, 26.2. IR spectrum (ATR): $\mathrm{V}_{\max }\left[\mathrm{cm}^{-1}\right]=2949,2867,1700,1661$, 1593, 1532, 1504, 1397, 1343, 1336, 1233, 1183, 1111, 1015, 872, 829, 783, 762. UV-Vis spectrum $\left(\mathbf{C D}_{2} \mathbf{C l}_{2}\right): \lambda_{\max }[\mathrm{nm}]\left(\varepsilon\left[\mathrm{M}^{-1} \mathrm{~cm}^{-1}\right]\right)=401(8,583)$. High Resolution Mass (ESI): $[\mathrm{M}]^{+}:$calculated: 791.4662, found: 791.4639, discrepancy: $-2.9 \mathrm{ppm}$. 


\section{N-Cyclohexyl-3,4-([b]-N,N-bis(p-2,4,4-trimethylpentane-2-yl)phenyl-1-hexyl-1H-}

\section{indole-6-amine)-1,8-naphthalene dicarboximide}

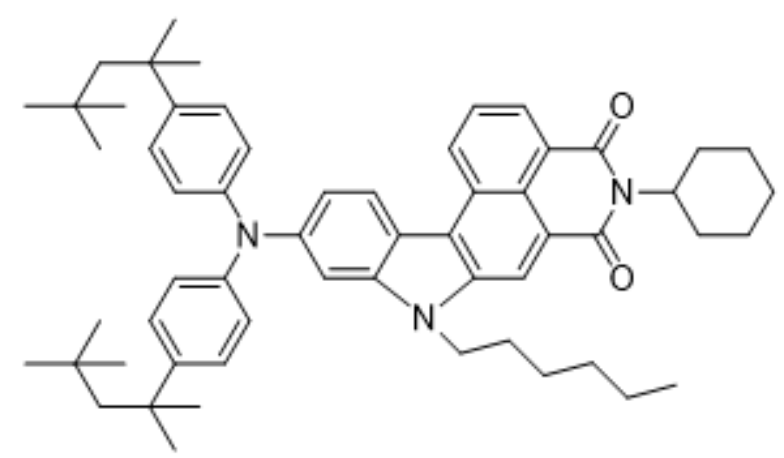

$550 \mathrm{mg}$ of N-cyclohexyl-4-(4-bis( $p$-2,4,4-trimethylpentane-2-yl)phenyl-amino-2-nitrophenyl)naphthalene 1,8-dicarboximide (0.694 mmol) and $545 \mathrm{mg}$ of triphenylphosphine $(2.08 \mathrm{mmol})$ were dissolved in $10 \mathrm{~mL}$ of $o$-dichlorobenzene and stirred at $182{ }^{\circ} \mathrm{C}$ and $300 \mathrm{~W}$ in the microwave (CEM, DISCOVER-S with external pressurised air cooling) for $8 \mathrm{~h}$. After removing the solvent under reduced pressure, the crude product was isolated via column chromatography on silica with dichloromethane and used directly for the next step. Yield (crude): $430 \mathrm{mg}$ orange solid (82\%).

$350 \mathrm{mg}$ of N-cyclohexyl-3,4-([b]-N,N -bis( $p$-2,4,4-trimethylpentane-2-yl)phenyl-1H-indole-6-amine)1,8 -naphthalene dicarboximide $(0.460 \mathrm{mmol})$ and $14 \mathrm{mg}$ of sodium hydride $(0.583 \mathrm{mmol})$ were mixed in a Schlenk tube. $15 \mathrm{~mL}$ of anhydrous dimethylformamide was added under argon. The solution was stirred for 30 minutes at room temperature. $230 \mathrm{mg}$ of bromohexane $(1.39 \mathrm{mmol})$ was added, and the solution was stirred for another $3 \mathrm{~h}$. After quenching the reaction with water, the solution was washed with water and hydrochloric acid (3:1), extracted with dichloromethane, and dried over magnesium sulfate. The crude product was purified via column chromatography on silica with dichloromethane. Yield: $270 \mathrm{mg}$ orange solid $(71 \%)$.

${ }^{1}$ H-NMR (700 MHz, THF, 298 K): $\delta$ [ppm]: $9.08(\mathrm{~d}, \mathrm{~J}=8.0,1 \mathrm{H}), 8.77(\mathrm{~s}, 1 \mathrm{H}), 8.51(\mathrm{~d}, \mathrm{~J}=8.8,1 \mathrm{H}), 8.46$ $(\mathrm{d}, \mathrm{J}=6.8,1 \mathrm{H}), 7.86(\mathrm{t}, \mathrm{J}=7.8,1 \mathrm{H}), 7.35(\mathrm{~d}, \mathrm{~J}=8.6,4 \mathrm{H}), 7.23(\mathrm{~d}, \mathrm{~J}=1.7,1 \mathrm{H}), 7.12(\mathrm{~m}, 5 \mathrm{H}), 5.09(\mathrm{t}, \mathrm{J}=$ 12.1, 1H), $4.43(\mathrm{t}, \mathrm{J}=7.1,2 \mathrm{H}), 2.73-2.61(\mathrm{~m}, 2 \mathrm{H}), 1.89(\mathrm{~d}, \mathrm{~J}=13.1,2 \mathrm{H}), 1.84-1.69(\mathrm{~m}, 9 \mathrm{H}$, partially overlaid with solvent), 1.51 - 1.24 (m, 21H), 0.88 - 0.78 (m, 21H). ${ }^{13}$ C-NMR (176 MHz, THF, 298 K): $\delta[\mathrm{ppm}]: 165.7,165.6,149.2,146.6,146.1,143.9,139.0,128.6,128.5,128.0,125.4,124.63,121.19$, 
120.94, 118.8, 116.7, 104., 58.3, 55.3, 54.5, 44.0, 39.4, 33.5, 33.0, 32.7, 32.4, 30.8, 30.4, 28.1, 28.0, 27.0, 23.8, 14.8. IR spectrum (ATR): $V_{\max }\left[\mathrm{cm}^{-1}\right]=2950,2927,2859,1690,1648,1607,1584,1505,1460$, 1384, 1316, 1256,1218, 1180, 1101, 1078, 890, 826, 795, 777, 739. UV-Vis spectrum $\left(\mathbf{C H}_{2} \mathbf{C l}_{2}\right): \lambda_{\max }$ $[\mathrm{nm}]\left(\varepsilon\left[\mathrm{M}^{-1} \mathrm{~cm}^{-1}\right]\right)=489(26,264)$. High Resolution Mass (ESI): [M] $]^{+}$: calculated: 843.5703, found: 843.5731, discrepancy: 3.3 ppm. Elemental analysis $\left(\mathbf{C}_{58} \mathbf{H}_{73} \mathbf{N}_{3} \mathbf{O}_{2}\right)$ : calculated: $82.52 \% \mathrm{C}, 8.72 \% \mathrm{H}, 4.98 \%$ $\mathrm{N}$; found: $81.78 \% \mathrm{C}, 8.67 \% \mathrm{H}, 5.07 \% \mathrm{~N}$.

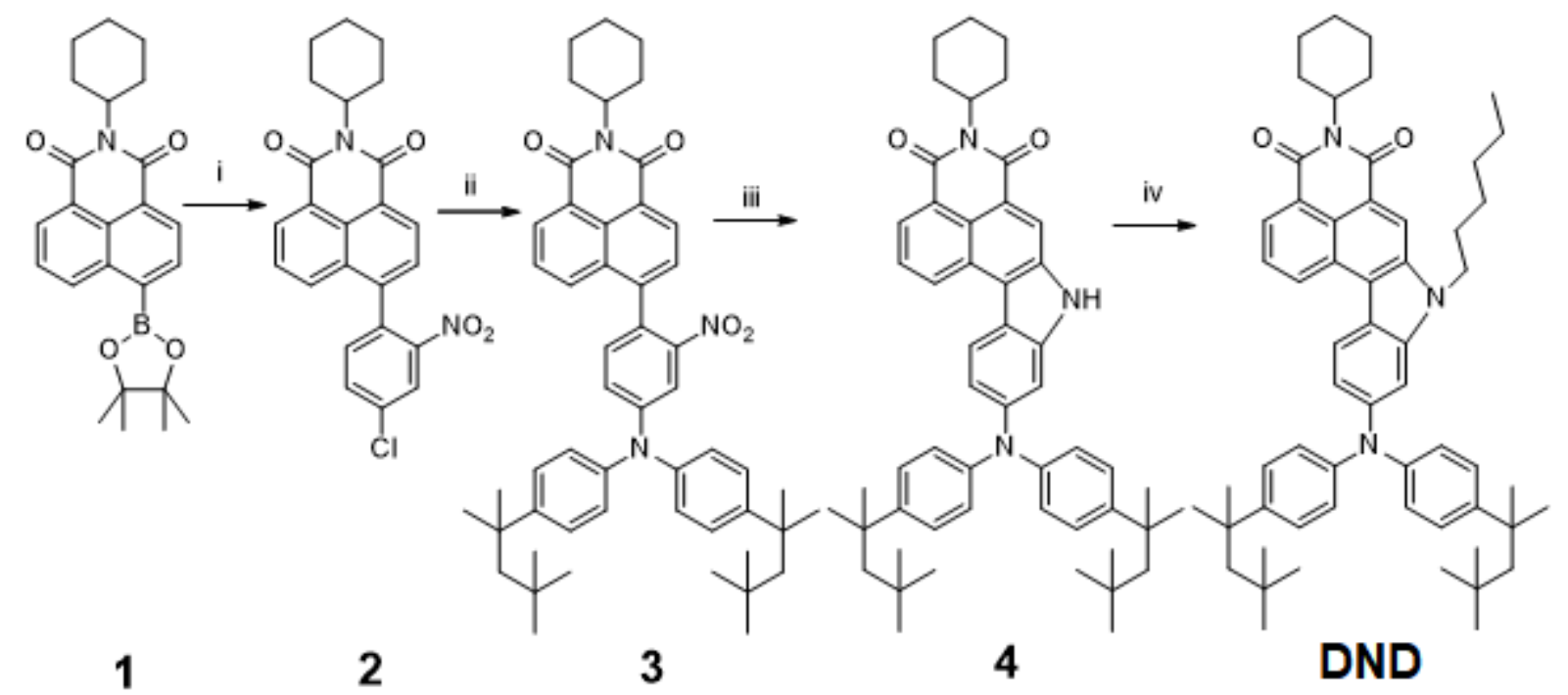

i) $\mathrm{K}_{2} \mathrm{CO}_{3}, \mathrm{Pd}(\mathrm{PPh} 3)_{4}$, toluene, water, ethanol, $80{ }^{\circ} \mathrm{C}, 60 \mathrm{~h}$, yield: $32 \%$; ii) (p-2,4,4-trimethylpentane-2-ylphenyl)amine, caesium carbonate, $\mathrm{Pd}_{2}(\mathrm{dba})_{3}$, BINAP, toluene, $100{ }^{\circ} \mathrm{C}, 16 \mathrm{~h}$, yield: $64 \%$ iii) triphenylphosphine, o-dichlorobenzene, microwave $\left(300 \mathrm{~W}, 182{ }^{\circ} \mathrm{C}, 8 \mathrm{~h}\right)$, yield: $82 \%$; iv) $\mathrm{NaH}, \mathrm{DMF}$, bromohexane, r.t., $3 \mathrm{~h}$, yield: $71 \%$.

The target DND was obtained via a four-step reaction starting from a carbon-carbon Suzuki coupling. Mixing pinacol boronate functionalized naphthaleneimide 1 with bromo-4-chloro-2-nitrobenzene, palladium catalyst, toluene, water, and ethanol at $80{ }^{\circ} \mathrm{C}$ for 2.5 days yielded 2 in $32 \% .2$ and $\operatorname{di}(p-$ octylphenyl)amine were then reacted under the Buchwald-Hartwig amination condition to generate 3 in 64\% yield. Subsequently, a microwave reactor treated $\mathbf{3}$ and triphenylphosphine in o-dichlorobenzene leading to 4 in $82 \%$. Owing to its reasonable solubility, 4 could be further alkylated by hexylbromide and 
$\mathrm{NaH}$ in DMF, which formed the final product DND in 71\%. The structures of compounds 1-4 and DND were proved by H-NMR, C-NMR, IR, and Mass spectroscopies.

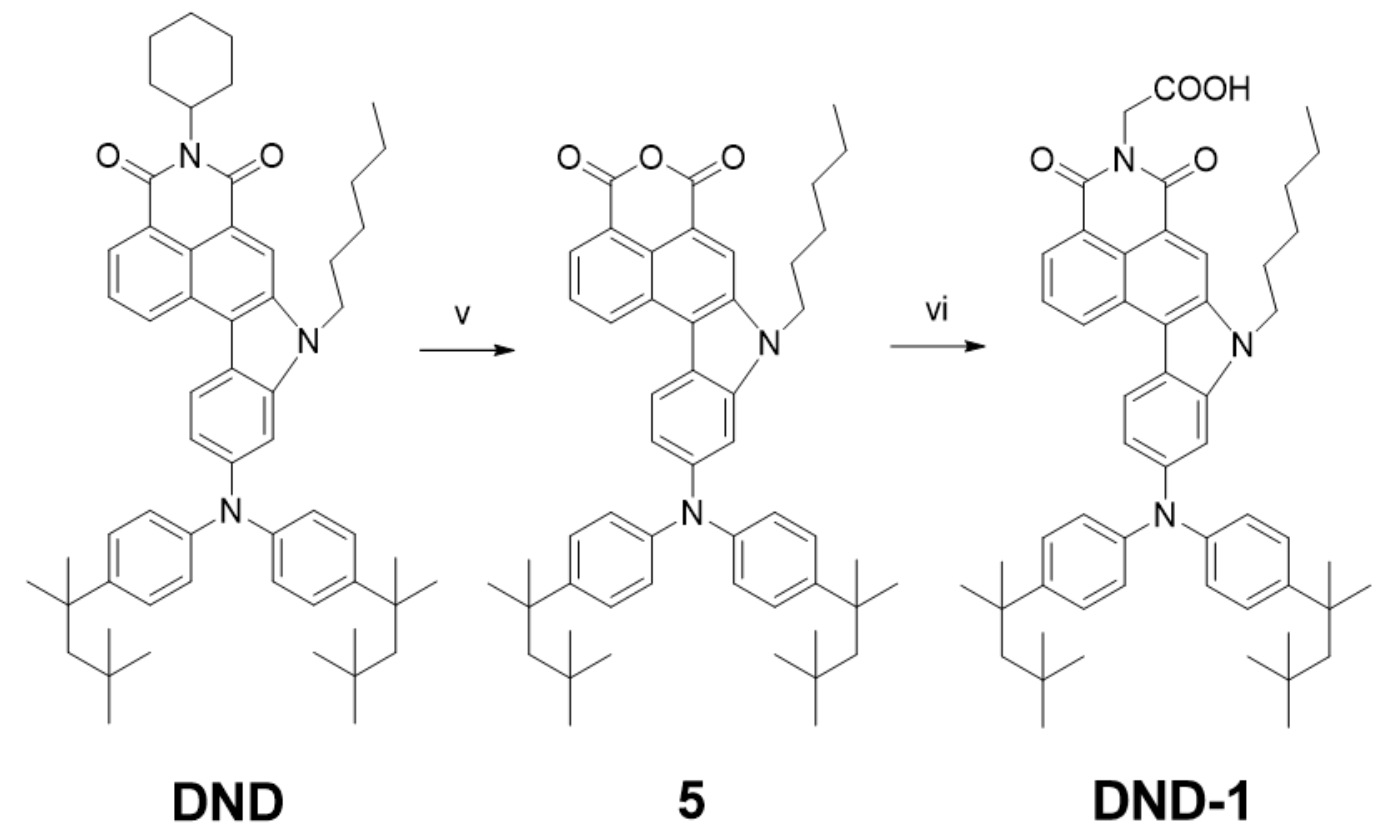

v) 2-methyl-2-butanol, $\mathrm{KOH}$, reflux, overnight, yield: $95 \%$; vi) glycine, imidazole, $140{ }^{\circ} \mathrm{C}$, overnight, yield: $87 \%$.

\section{N-Carboxymethyl-3,4-([b]-N,N-bis(p-2,4,4-trimethylpentane-2-yl)phenyl-1H-indole-6-amine)-1,8- naphthalene dicarboximide}

$170 \mathrm{mg}$ of N-cyclohexyl-3,4-([b]-N,N -bis(p-2,4,4-trimethylpentane-2-yl)phenyl-1H-indole-6-amine)1,8-naphthalene dicarboximide ( $0.201 \mathrm{mmol})$ was dissolved in $10 \mathrm{~mL}$ of 2-methyl-2-butanol. $450 \mathrm{mg}$ of potassium hydroxide $(8.04 \mathrm{mmol})$ was added, the reaction mixture degassed and refluxed under argon overnight. The reaction mixture was poured into an ice water/acetic acid mixture (10:2). The precipitate was filtered, washed with water, and after drying dissolved in dichloromethane. 1-2 $\mathrm{mL}$ of acetic acid was added, and the solution was stirred for 1-2 days. After removal of the dichloromethane under reduced pressure, methanol was added. The precipitate was filtered and washed with methanol. The formed anhydride was used directly for the next step without further purification. Yield (crude): $145 \mathrm{mg}$ red solid 
$(95 \%)$.

$80 \mathrm{mg}$ of the crude anhydride $5(0.104 \mathrm{mmol}), 1 \mathrm{~g}$ of glycine $(13.4 \mathrm{mmol})$, and $2 \mathrm{~g}$ of imidazole (29.4 mmol) were mixed in a Schlenk tube and stirred under argon at $140{ }^{\circ} \mathrm{C}$ overnight. After cooling down, dilute hydrochloric acid (water:acid (5:1)) was added. The precipitate was filtered and washed with water. The crude product was purified by column chromatography on silica gel with dichloromethane, tetrahydrofuran, and acetic acid. Yield: $75 \mathrm{mg}$ orange solid (87\%).

${ }^{1}$ H-NMR (700 MHz, THF, 298 K): $\delta$ [ppm]: $9.10(\mathrm{~d}, \mathrm{~J}=8.3,1 \mathrm{H}), 8.72(\mathrm{~s}, 1 \mathrm{H}), 8.50$ (d, J = 8.8, $\left.1 \mathrm{H}\right), 8.46$ $(\mathrm{d}, \mathrm{J}=7.2,1 \mathrm{H}), 7.86(\mathrm{t}, \mathrm{J}=7.8,1 \mathrm{H}), 7.36(\mathrm{~d}, \mathrm{~J}=8.6,4 \mathrm{H}), 7.23(\mathrm{~d}, \mathrm{~J}=1.7,1 \mathrm{H}), 7.15-7.10(\mathrm{~m}, 5 \mathrm{H}), 4.83$ $(\mathrm{s}, 2 \mathrm{H}), 4.41(\mathrm{t}, \mathrm{J}=7.2,2 \mathrm{H}), 1.83-1.77(\mathrm{~m}, 6 \mathrm{H}), 1.40(\mathrm{~s}, 12 \mathrm{H}), 1.32-1.24(\mathrm{~m}, 6 \mathrm{H}), 0.88-0.77(\mathrm{~m}, 21 \mathrm{H})$. ${ }^{13}$ C-NMR (176 MHz, THF, 298 K): $\delta$ [ppm]: 167.0, 164.9, 164.8, 149.3, 146.6, 146.2, 144.0, 138.8, $130.5,128.8,128.5,128.3,128.0,125.5,125.4,124.7,124.4,121.7,119.8,118.8,118.7,116.9,104.3$, 58.3, 44.1, 41.9, 39.4, 33.5, 33.0, 32.7, 32.4, 30.8, 28.1, 23.8, 14.8. IR spectrum (ATR): $v_{\max }\left[\mathrm{cm}^{-1}\right]=$ 2946, 2867, 1721, 1695, 1661, 1623, 1589, 1513, 1464, 1389, 1358, 1294, 1245, 1178, 1090, 825, 773, 738. UV-Vis spectrum $\left(\mathbf{C H}_{2} \mathbf{C l}_{2}\right): \lambda_{\max }[\mathrm{nm}]\left(\varepsilon\left[\mathrm{M}^{-1} \mathrm{~cm}^{-1}\right]\right)=335(26,910), 502(25,252)$. High Resolution Mass (ESI): $[\mathrm{M}]^{+}$: calculated: 819.4575, found: 819.4980, discrepancy: 0.6 ppm. Elemental analysis $\left(\mathbf{C}_{54} \mathbf{H}_{65} \mathbf{N}_{3} \mathbf{O}_{4}\right)$ : calculated: $79.08 \% \mathrm{C}, 7.99 \% \mathrm{H}, 5.12 \% \mathrm{~N}$; found: $78.64 \% \mathrm{C}, 8.21 \% \mathrm{H}, 5.00 \% \mathrm{~N}$. 


\section{Supplementary Note 2. Steady-state spectroscopic data and the fluorescence lifetime}

\section{Measurement of absolute fluorescence quantum yield}

The fluorescence quantum yield was calculated using the following equation, ${ }^{1}$

$$
\Phi_{f l}=\frac{N_{e m}}{N_{a b s}}=\frac{E_{A}-E_{B}}{S_{B}-S_{A}}
$$

where $\Phi_{f l}$ represents the absolute fluorescence quantum yield of the sample, $N_{a b s}$ and $N_{e m}$ are the number of photons that absorbed or emitted, respectively, the subscripts A and B represent the sample and the blank (i.e. neat solvent filled in a cell), respectively, $S$ is the area of the excitation pulse within the bandwidth of the pulse, and $E$ corresponds to the integrated area of each emission band.

To estimate the rate constant of non-radiative deactivation $\left(k_{n r}\right)$, we used the following equation.

$$
k_{n r}=\left(1-\Phi_{f l}\right) / \tau_{f l}
$$

where $\Phi_{f l}$ is the fluorescence quantum yield calculated by equation (S1) and $\tau_{f l}$ is a fluorescence lifetime obtained from TCSPC.

\section{Supplementary Note 3. Details on DFT and TDDFT results}

The comparison of various functionals and basis sets with the solvents for the electronic transitions, structural parameters, and dipole moments are shown in Tables S1 - S5. The detailed methods for DFT and TDDFT are described in the Experimental Methods.

\section{Supplementary Note 4. Broadband transient absorption experiments and data analysis Singular value decomposition (SVD) analysis and kinetic modelling}

The broadband transient absorption setup and experimental conditions are described in the Experimental Methods. The singular value decomposition (SVD) analysis was applied for kinetic analysis of transient absorption (TA) spectra. The method for SVD analysis is described in previous publications. ${ }^{2-4}$ By the global fitting of the right-singular values (rSVs), which corresponds to time-dependent absorbance change, the TA data sets of THF and DMSO were fit with four time constants, which are summarized in Table 2. Based on the four time constants and four spectrally distinct intermediates, we assumed a sequential 
kinetic model. ${ }^{5}$

$$
A \stackrel{\tau_{1}}{\longrightarrow} B \stackrel{\tau_{2}}{\longrightarrow} C \stackrel{\tau_{3}}{\longrightarrow} D \stackrel{\tau_{4}}{\longrightarrow} G S
$$

We implemented a principal component analysis (PCA) following the sequential kinetic model whereby the experimental TA spectra were decomposed into four species-associated difference spectra (SADS) ${ }^{6}$ according to the four species.

$$
\begin{aligned}
& -\Delta T / T(\mathrm{t}, \lambda)=\sum_{i}^{4} C_{i}^{*}(t) \cdot \operatorname{SADS}_{i}(\lambda) \\
& C_{i}^{*}(t)=C_{i}^{S A D S}(t) \otimes \operatorname{IRF}(\mathrm{t}, \sigma)
\end{aligned}
$$

where $-\Delta T / T(t, \lambda)$ is the theoretical TA spectra at given time delays and wavelengths, $\operatorname{SADS}(\lambda)$ is the SADS for the $i^{\text {th }}$ species, and $C_{i}^{*}(t)$ is the time-dependent population of the $i^{\text {th }}$ species, which is obtained by the convolution with the instrumental response function $(\operatorname{IRF}(t, \sigma))$ of the experiment. The discrepancy between the theoretical and experimental TA spectra was minimized via the Nelder-mead simplex method.

\section{Excitation wavelength dependence on ICT dynamics.}

We performed TA measurements to investigate the excitation wavelength dependence of DND in DMSO after $400 \mathrm{~nm}$ and $473 \mathrm{~nm}$ excitation (Figure $\mathrm{S} 7 \mathrm{a}$ and $\mathrm{S} 7 \mathrm{~b}$ ), assigned to the $\mathrm{S}_{0} \rightarrow \mathrm{S}_{2}$ transition and the $\mathrm{S}_{0}$ $\rightarrow \mathrm{S}_{1}$ transition from the TDDFT calculations, respectively. The overall spectral changes accompanying with the rise of new ESA around $530-580 \mathrm{~nm}$ are almost identical for both excitation conditions (Figure S7c and S7d), but the kinetics upon $400 \mathrm{~nm}$ excitation shows an additional time constant of $61 \mathrm{fs}$, which is attributable to the internal conversion from $S_{2}$ to $S_{1}$ due to the excess energy of $\sim 0.48 \mathrm{eV}$ by an excitation pulse (Figure S7e). We can confirm that the dependence on the photon energy of the pump pulse is absent below $3.10 \mathrm{eV}$ of the excitation photon energy and the additional deactivation pathways such as the intersystem crossing from the $S_{2}$ state can be excluded. 


\section{Supplementary Note 5. Photovoltaic performance of DND}

The charge carrier dynamics observed with broadband TA spectroscopy in this work suggest that the intramolecular charge transfer occurring in the excited states of DND would facilitate the charge injection into the electron acceptor when applied to solar cells. While the DND dye would be attached to an external electron acceptor (for example, $\mathrm{TiO}_{2}$ ) in the solar cell, the electron will be easily injected to the acceptor at their interface due to the intrinsic electron-donating character of $\mathrm{N}$-annulated rylene, as evidenced by the ultrafast formation of the CS state. Also, the CS state generated in DND can help to enhance the performance of photovoltaics. ${ }^{7,8}$

To examine the performance of DND in a solar cell, we fabricated the DSSC film using DND as a photosensitizer and characterized its performance. To facilitate the attachment of DND onto the $\mathrm{TiO}_{2}$ surface, we substituted the cyclohexyl group in dicarboximide moiety with the carboxymethyl group to form DND-1. The details of the fabrication of DSSC are summarized in the Experimental Methods. The absorption spectra and the device efficiencies are presented in Figure S10. Figure S10a and 10b indicate the absorption spectra of DND-1 in THF and DND-1 attached to the $\mathrm{TiO}_{2}$ electrode, respectively. The substitution of the terminal group does not alter the absorption spectrum (Figure S10a), but the absorption spectrum of DND-1 on the $\mathrm{TiO}_{2}$ electrode shows the prominent spectral red shift (Figure S10b). To estimate the device performance, we tested the cell efficiencies at an irradiance of $100 \mathrm{~mW} \mathrm{~cm}{ }^{-2}$ under AM 1.5G conditions. As can be seen in Figure S10c, the maximum external quantum efficiency (EQE) is $50 \%$ at $520 \mathrm{~nm}$, where the intensity of the sunlight is maximum. The current density-voltage (I-V) curve in Figure S10d) shows an open-circuit voltage ( $\mathrm{V}_{\text {OC }}$ ) of $980 \mathrm{mV}$, a short-circuit current density (ISC) of $5.2 \mathrm{~mA} \mathrm{~cm}^{-2}$, and a fill factor (FF) of 0.640 , giving a PCE of $3.2 \%$, as summarized in Table S6. The results of the photovoltaic performance indicate that the electron injection from NANDID to the conduction band of $\mathrm{TiO}_{2}$ occurs effectively, leading to the current generation. 
Table S1. The absorption and emission energies (in $\mathrm{nm}$ ) in the gas phase and three solvents calculated using (TD)DFT/ 6-311++G(d,p) with the IEFPCM method and various functionals. Values in parentheses are the oscillator strengths. The experimental values for the absorption and emission energies (in $\mathrm{nm}$ ) are listed for comparison.

\begin{tabular}{|c|c|c|c|c|c|c|}
\hline \multicolumn{7}{|c|}{ Absorption } \\
\hline & PBE0 & CAM-B3LYP & $\omega \mathrm{B} 97 \mathrm{XD}$ & MN12-SX & MN15 & Exp. \\
\hline Gas & $485.2(0.4679)$ & $391.9(0.7243)$ & $378.2(0.7471)$ & $\begin{array}{c}517.2(0.0075) \\
514.5(0.3646)^{\mathrm{a}}\end{array}$ & $426.4(0.6315)$ & - \\
\hline Cyclohexane & $508.2(0.5679)$ & $405.9(0.8647)$ & $390.3(0.8995)$ & $538.1(0.4689)$ & $443.5(0.7571)$ & 482.2 \\
\hline Tetrahydrofuran & $522.6(0.5517)$ & $412.3(0.8496)$ & $395.2(0.8853)$ & $554.3(0.4596)$ & $452.3(0.7384)$ & 480.1 \\
\hline Dimethylsulfoxide & $528.4(0.5505)$ & $415.0(0.8486)$ & $397.2(0.8838)$ & $561.0(0.4588)$ & $455.9(0.7360)$ & 487.6 \\
\hline \multicolumn{7}{|c|}{ Emission } \\
\hline & TD-PBE0 & TD-CAM-B3LYP & TD- $\omega$ B $97 X D$ & TD-MN12-SX & TD-MN15 & Exp. \\
\hline Gas & $603.1(0.1280)$ & $441.6(0.7734)$ & $429.6(0.8074)$ & - & $473.2(0.6330)$ & - \\
\hline Cyclohexane & $589.3(0.3475)$ & $465.4(0.9461)$ & $452.4(0.9901)$ & $646.0(0.2424)$ & $497.2(0.8007)$ & 504.1 \\
\hline Tetrahydrofuran & $603.8(0.5780)$ & $496.2(1.1147)$ & $481.8(1.1616)$ & $654.8(0.4144)$ & $528.6(0.9695)$ & 598.7 \\
\hline Dimethylsulfoxide & $616.5(0.6662)$ & 511.9 (1.1832) & $496.8(1.2284)$ & $664.5(0.4942)$ & $544.4(1.0405)$ & 670.6 \\
\hline
\end{tabular}

a. The $S_{2}$ state. 
Table S2. The absorption energies (in $\mathrm{nm}$ ) and the dipole moments of DND in the gas phase and three solvents calculated using (TD)DFT/ 6-311G(d,p) or 6-31G(d,p) with the IEFPCM method and various functionals. Values in parentheses and italic are the oscillator strengths and the dipole moments (in D), respectively.

\begin{tabular}{|c|c|c|c|c|c|}
\hline \multicolumn{6}{|c|}{$6-311 G(d, p)$} \\
\hline & PBE0 & CAM-B3LYP & $\omega \mathrm{B} 97 \mathrm{XD}$ & MN12-SX & MN15 \\
\hline Gas & $457.8,6.9(0.4805)$ & $384.8,6.4(0.7471)$ & $372.9,6.3(0.7642)$ & $494.1,6.8(0.4152)$ & $419.8,6.5(0.6487)$ \\
\hline Cyclohexane & $497.0,7.8(0.5800)$ & $397.7,7.2(0.8876)$ & $384.3,7.0(0.9165)$ & $516.7,7.7(0.5056)$ & $456.0,7.3(0.7717)$ \\
\hline Tetrahydrofuran & $509.5,8.8(0.5620)$ & $403.0,8.0(0.8704)$ & $388.4,7.8(0.9008)$ & $531.1,8.7(0.4897)$ & $443.1,8.1(0.7514)$ \\
\hline Dimethylsulfoxide & $514.4,9.2(0.5597)$ & $405.1,8.3(0.8685)$ & $390.1,8.1(0.8990)$ & $536.8,9.1(0.4872)$ & $446.1,8.4(0.7482)$ \\
\hline \multicolumn{6}{|c|}{$6-31 G(d, p)$} \\
\hline & PBE0 & CAM-B3LYP & $\omega \mathrm{B} 97 \mathrm{XD}$ & MN12-SX & MN15 \\
\hline Gas & $474.6,6.8(0.4799)$ & $381.4,6.4(0.7596)$ & $369.7,6.2(0.7806)$ & $492.6,6.8(0.4138)$ & $416.7,6.4(0.6529)$ \\
\hline Cyclohexane & $496.0,7.7(0.5764)$ & $394.3,7.1(0.8971)$ & $381.1,7.0(0.9300)$ & $515.5,7.7(0.5016)$ & $432.4,7.2(0.7719)$ \\
\hline Tetrahydrofuran & $508.7,8.7(0.5591)$ & $399.6,7.8(0.8791)$ & $385.3,7.7(0.9135)$ & $530.1,8.7(0.4865)$ & $440.0,7.9(0.7515)$ \\
\hline Dimethylsulfoxide & $513.7,9.0(0.5571)$ & $401.7,8.1(0.8771)$ & $387.0,8.0(0.9116)$ & $536.0,9.0(0.4844)$ & $443.0,8.2(0.7481)$ \\
\hline
\end{tabular}


Table S3. The geometric parameters of dihedral angles for C-C-N-C (in ${ }^{\circ}$ ) and C-N bond lengths (in $\AA$ ) between DPA and NANDID for the ground state and the lowest singlet excited state ( $\mathrm{S}_{1} / \mathrm{ICT}$ ) calculated using (TD)DFT/ 6-311++G(d,p) with the IEFPCM method and various functionals.

\begin{tabular}{c|c|c|c|c|c}
\hline \multicolumn{7}{c}{$\mathrm{S}_{0}$-optimized state } \\
\hline & PBE0 & CAM-B3LYP & $\omega$ B97XD & MN12-SX & MN15 \\
\hline Gas & $32.4,1.404$ & $30.8,1.406$ & $31.0,1.407$ & $32.1,1.403$ & $31.5,1.409$ \\
\hline Cyclohexane & $31.7,1.403$ & $30.1,1.405$ & $30.3,1.406$ & $31.3,1.402$ & $30.8,1.408$ \\
\hline Tetrahydrofuran & $30.7,1.401$ & $29.0,1.404$ & $29.3,1.405$ & $30.5,1.401$ & $29.9,1.407$ \\
\hline Dimethylsulfoxide & $30.0,1.401$ & $28.1,1.404$ & $28.5,1.405$ & $30.1,1.401$ & $29.5,1.407$ \\
\hline \multicolumn{7}{|c|}{ S $_{1}$-optimized state } \\
\hline \multicolumn{7}{c|}{ PBE0 } & CAM-B3LYP & $\omega$ B97XD & MN12-SX & MN15 \\
\hline Gyclohexane & $54.2,1.429$ & $32.7,1.388$ & $30.5,1.386$ & - & $39.1,1.404$ \\
\hline Tetrahydrofuran & $43.4,1.410$ & $27.2,1.375$ & $25.1,1.374$ & $47.0,1.420$ & $31.9,1.388$ \\
\hline Dimethylsulfoxide & $40.3,1.403$ & $25.9,1.372$ & $23.8,1.371$ & $43.8,1.414$ & $30.6,1.384$ \\
\hline
\end{tabular}


Table S4. The geometric parameters of dihedral angles for C-C-N-C (in ${ }^{\circ}$ ) and C-N bond lengths (in $\AA$ ) between DPA and NANDID for the ground state calculated using DFT/ 6-311G(d,p) or 6-31G(d,p) with the IEFPCM method and various functionals.

\begin{tabular}{|c|c|c|c|c|c|}
\hline \multicolumn{6}{|c|}{$6-311 G(d, p)$} \\
\hline & PBE0 & CAM-B3LYP & $\omega \mathrm{B} 97 \mathrm{XD}$ & MN12-SX & MN15 \\
\hline Gas & $32.3,1.403$ & $30.9,1.406$ & $31.2,1.407$ & $32.0,1.403$ & $31.5,1.409$ \\
\hline Cyclohexane & $31.7,1.402$ & $30.3,1.405$ & $30.6,1.406$ & $31.2,1.402$ & $31.1,1.408$ \\
\hline Tetrahydrofuran & $30.6,1.401$ & $29.2,1.404$ & $29.4,1.405$ & $30.4,1.401$ & $30.3,1.407$ \\
\hline Dimethylsulfoxide & $29.9,1.401$ & $28.3,1.403$ & $28.5,1.404$ & $30.1,1.401$ & $29.9,1.407$ \\
\hline \multicolumn{6}{|c|}{$6-31 G(d, p)$} \\
\hline & PBE0 & CAM-B3LYP & $\omega \mathrm{B} 97 \mathrm{XD}$ & MN12-SX & MN15 \\
\hline Gas & $32.6,1.405$ & $31.6,1.407$ & $31.8,1.408$ & $32.3,1.405$ & $32.3,1.412$ \\
\hline Cyclohexane & $32.1,1.404$ & $31.1,1.406$ & $31.3,1.407$ & $31.6,1.404$ & $31.8,1.411$ \\
\hline Tetrahydrofuran & $31.1,1.403$ & $30.3,1.406$ & $30.4,1.407$ & $30.8,1.403$ & $31.2,1.410$ \\
\hline Dimethylsulfoxide & $30.5,1.402$ & $29.7,1.405$ & $29.9,1.406$ & $30.5,1.403$ & $30.9,1.410$ \\
\hline
\end{tabular}


Table S5. Electric dipole moments (in D) of the ground state, FC state, and the lowest singlet excited state $\left(\mathrm{S}_{1} / \mathrm{ICT}\right)$ of DND calculated by (TD)DFT/ 6-311++G(d,p) with the IEFPCM method and various functionals.

\begin{tabular}{|c|c|c|c|c|c|}
\hline \multicolumn{6}{|c|}{ Ground state / FC state } \\
\hline & PBE0 & CAM-B3LYP & $\omega \mathrm{B} 97 \mathrm{XD}$ & MN12-SX & $\mathrm{MN} 15$ \\
\hline Gas & $6.9 / 24.7$ & $6.5 / 17.6$ & $6.3 / 15.3$ & $6.8 /-$ & $6.5 / 20.6$ \\
\hline Cyclohexane & $7.9 / 28.0$ & $7.4 / 20.2$ & $7.1 / 17.6$ & $7.8 / 29.1$ & $7.4 / 23.6$ \\
\hline Tetrahydrofuran & $9.0 / 31.3$ & $8.2 / 22.7$ & $7.9 / 19.9$ & $8.8 / 32.8$ & $8.3 / 26.5$ \\
\hline Dimethylsulfoxide & $9.4 / 32.7$ & $8.6 / 23.7$ & $8.2 / 20.8$ & $9.3 / 34.3$ & $8.7 / 27.6$ \\
\hline \multicolumn{6}{|c|}{$\mathrm{S}_{1} / \mathrm{ICT}$ state } \\
\hline & TD-PBE0 & TD-CAM-B3LYP & TD- $\omega$ B97XD & TD-MN12-SX & TD-MN15 \\
\hline Gas & 30.6 & 17.3 & 15.8 & - & 20.5 \\
\hline Cyclohexane & 31.5 & 20.3 & 18.7 & 32.9 & 23.2 \\
\hline Tetrahydrofuran & 33.1 & 23.5 & 22.0 & 35.4 & 26.3 \\
\hline Dimethylsulfoxide & 34.1 & 25.0 & 23.4 & 36.6 & 27.7 \\
\hline
\end{tabular}


Table S6. Optical and electrochemical properties of DND and photovoltaic performance of the cell measured at an irradiance of $100 \mathrm{~mW} \mathrm{~cm}^{-2}$, simulated AM $1.5 \mathrm{G}$ sunlight.

\begin{tabular}{lccccccccc}
\hline & $\begin{array}{c}\lambda_{\max }(\mathbf{n m}) / \\
\boldsymbol{\varepsilon}\left(\mathbf{M}^{-1} \mathbf{c m}^{-1}\right)\end{array}$ & $\begin{array}{c}\text { LUMO } \\
(\mathbf{e V})\end{array}$ & $\begin{array}{c}\text { HOMO } \\
(\mathbf{e V})\end{array}$ & $\begin{array}{c}\text { Bandgap } \\
(\mathbf{e V})\end{array}$ & $\begin{array}{c}\mathbf{E Q E}_{\max } \\
(\%)\end{array}$ & $\begin{array}{c}\mathbf{V}_{\mathbf{O C}} \\
(\mathbf{m V})\end{array}$ & $\begin{array}{c}\mathbf{I}_{\mathbf{S C}} \\
\left(\mathbf{m A ~ c m} \mathbf{~ c m}^{-2}\right)\end{array}$ & FF (\%) & PCE (\%) \\
\hline DND-1 & $484 / 25,100$ & -3.1 & -4.8 & 1.7 & 50 & 980 & -5.2 & 64 & 3.2 \\
\hline
\end{tabular}


a

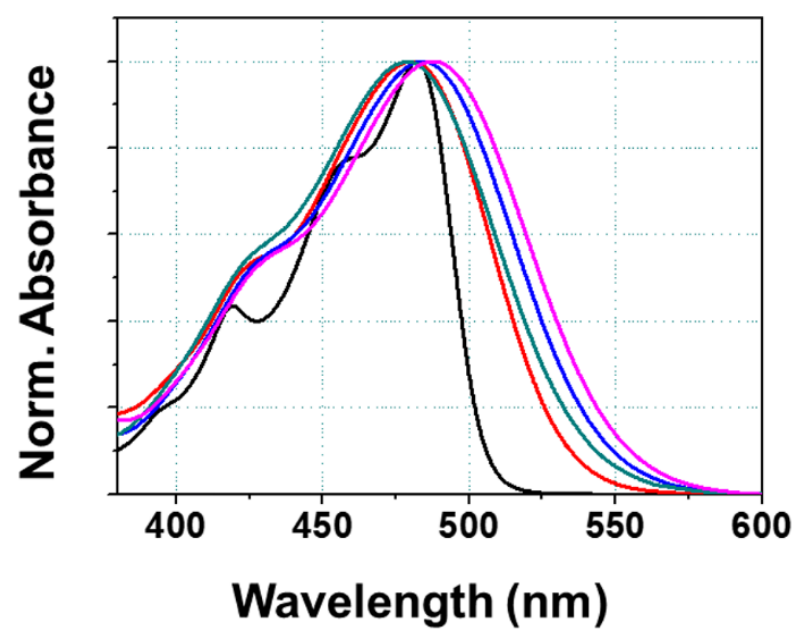

b

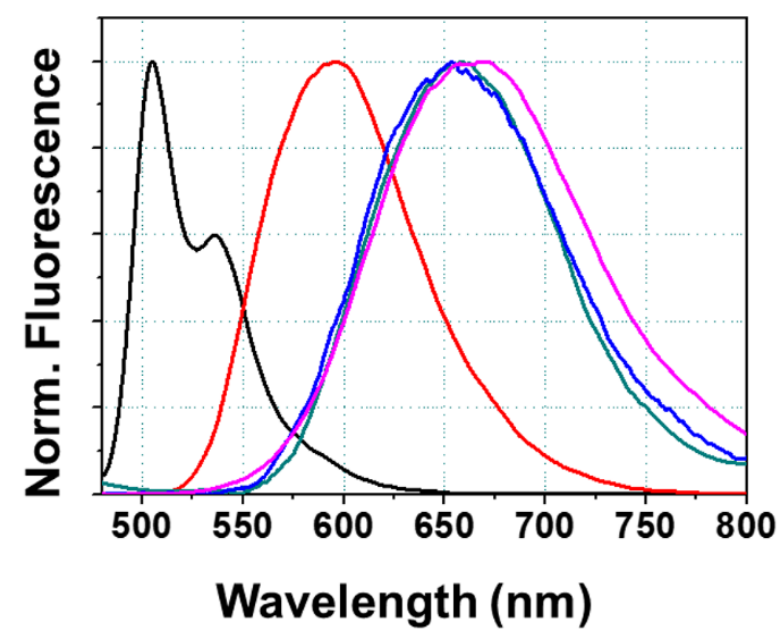

Figure S1. The normalized steady-state (a) absorption and (b) emission spectra with the excitation wavelength of $470 \mathrm{~nm}$ of DND in all five solvents: CHX (black), THF (red), DMF (blue), MeCN (dark cyan), and DMSO (magenta). 


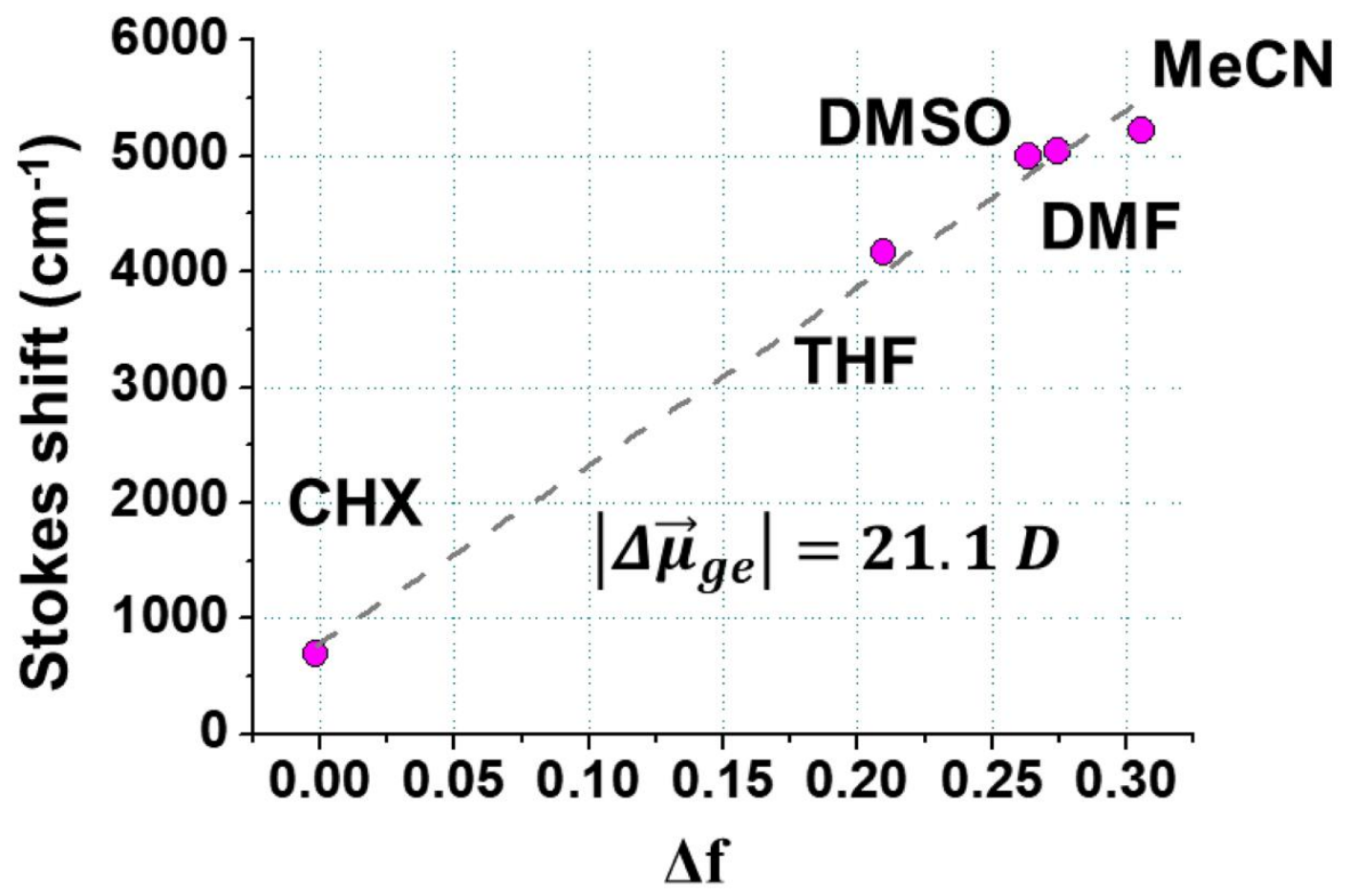

Figure S2. Lippert-Mataga plot for DND in various solvents. The difference of dipole moments between the ground state and the excited state $\left(\Delta \vec{\mu}_{e g}\right)$ was estimated to be $21.1 \mathrm{D}$ from the slope of the plot. The $\mathrm{R}^{2}$ of the linear fit is 0.980 . 


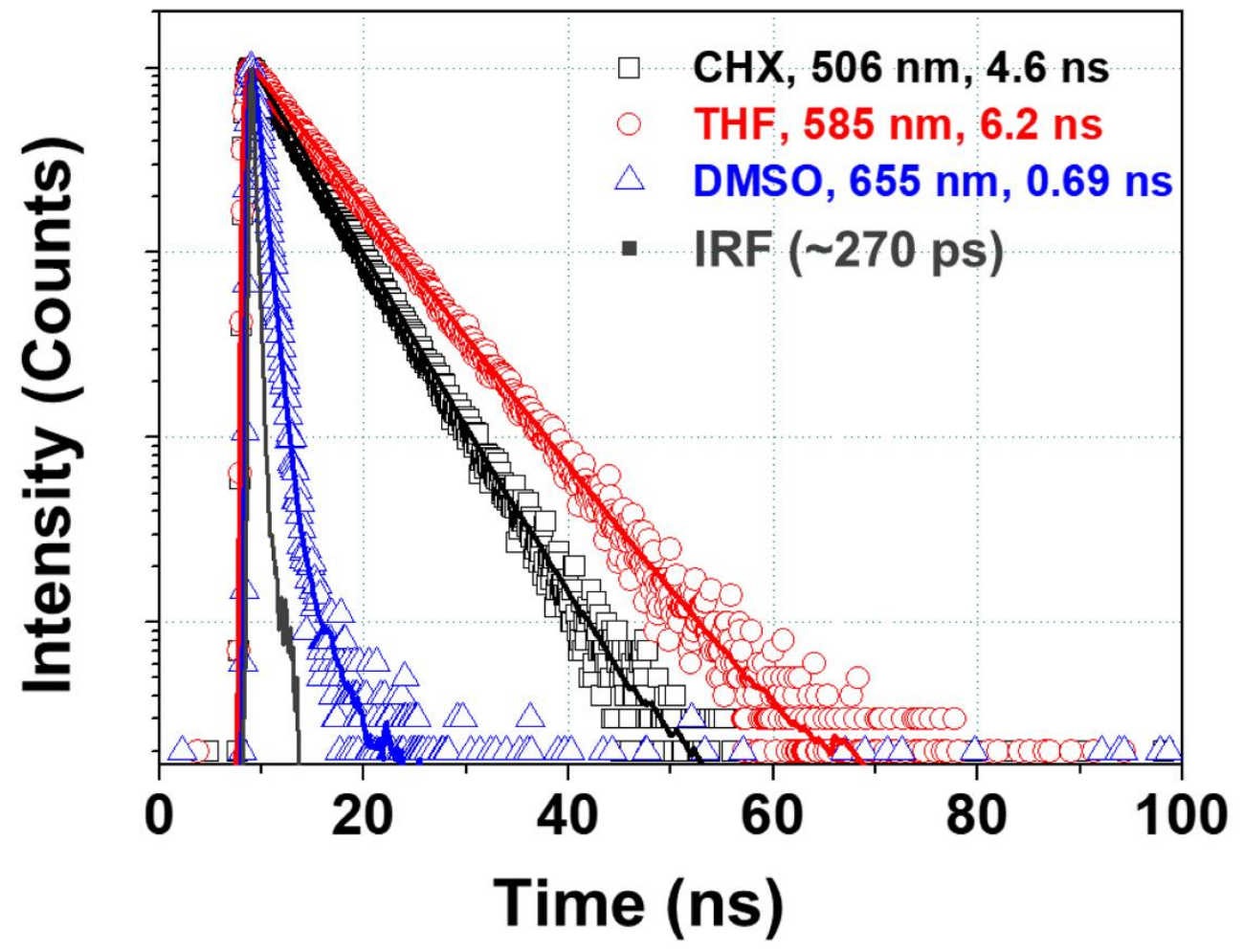

Figure S3. Time-correlated single-photon counting (TCSPC) data of DND in CHX (black, squares), THF (red, circles), and DMSO (blue, triangles) and their fit. The monitored emission wavelength for measurement and fluorescence lifetimes are indicated in the legend. The absorbance was adjusted to below 0.2 at the excitation wavelength of $470 \mathrm{~nm}$ for each sample. The instrument response function (IRF) of TCSPC was about 270 ps. The band origin of all monitored emission wavelength is from the lowest emission band and the local emission band is absent in polar solvents. 
a

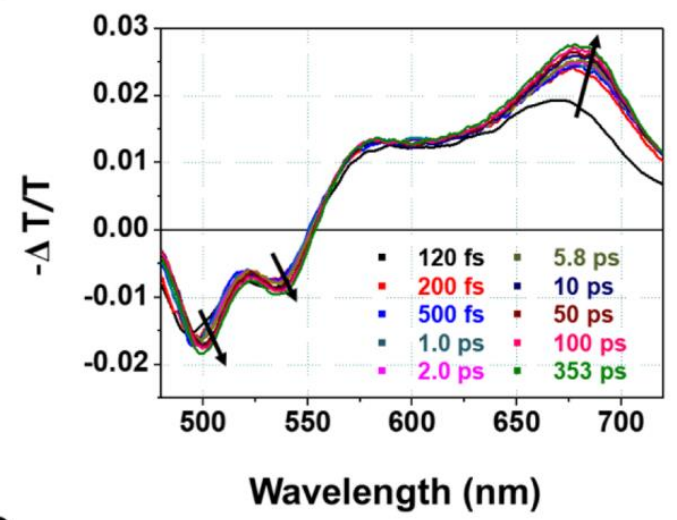

b

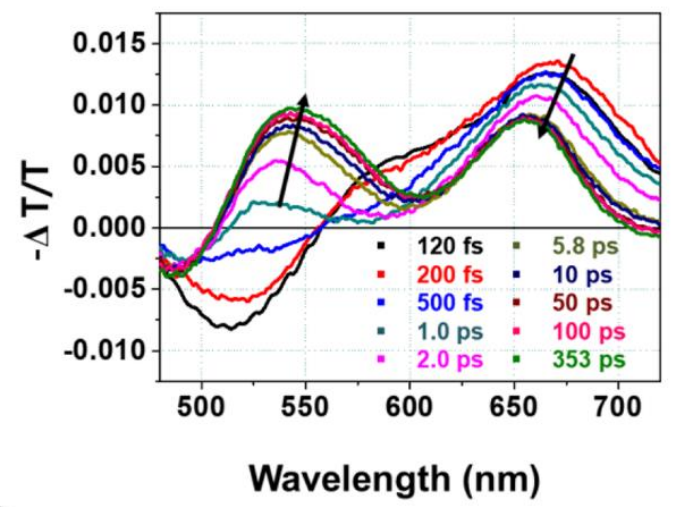

c

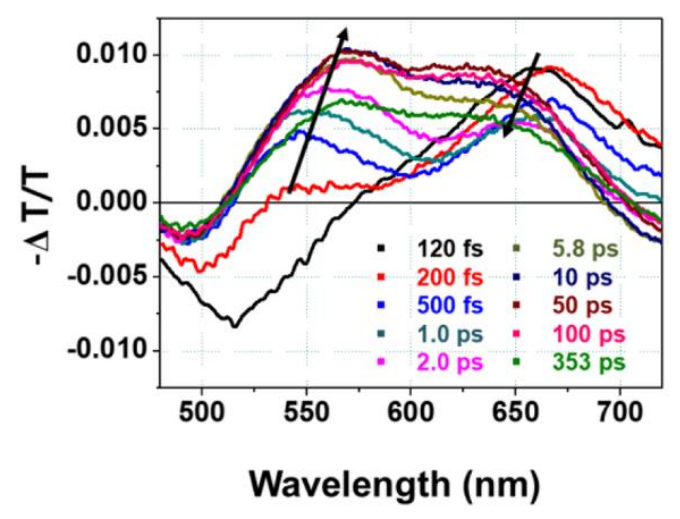

d

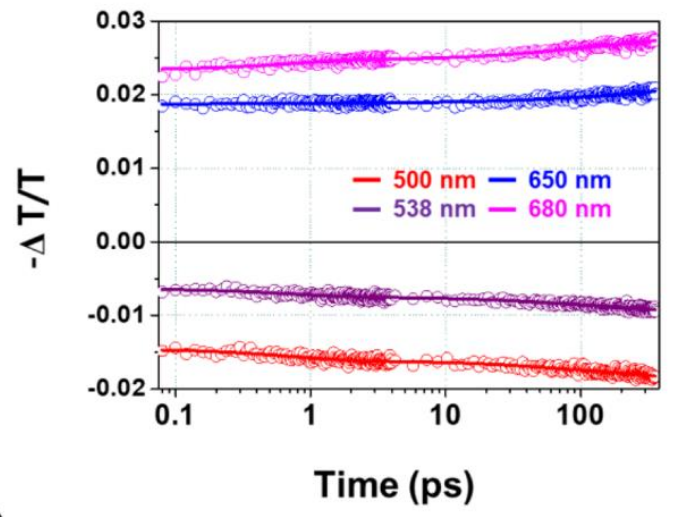

$\mathbf{e}$

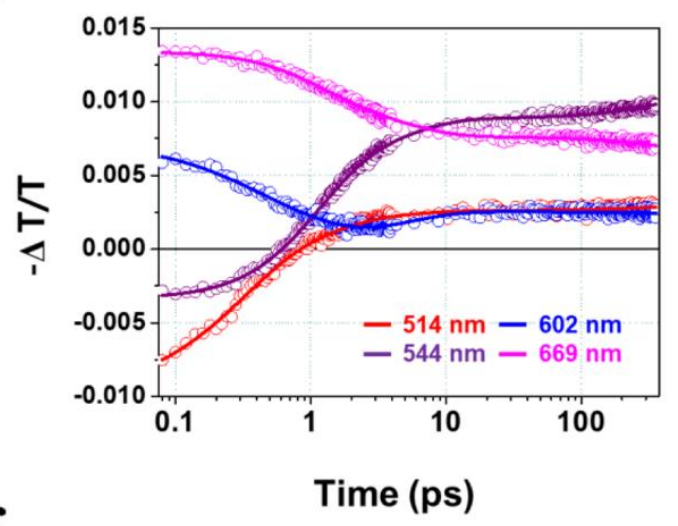

$\mathbf{f}$

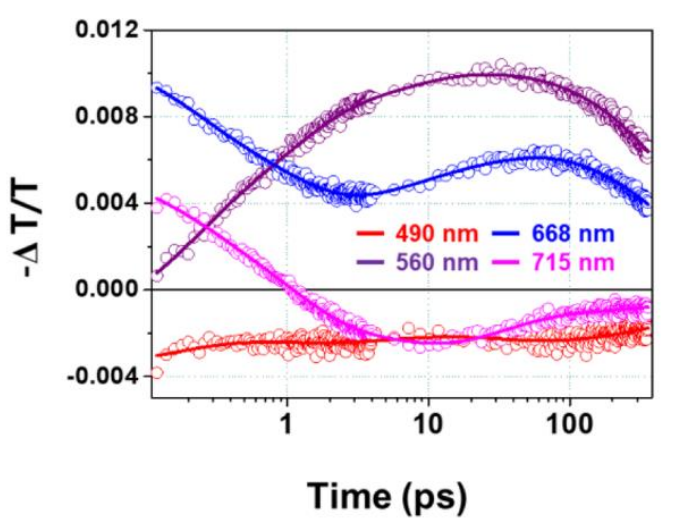

Figure S4. The transient absorption spectra at representative time delays and the kinetics at depicted wavelengths of DND after $473 \mathrm{~nm}$ excitation in (a,d) CHX, (b,e) THF, and (c,f) DMSO. 


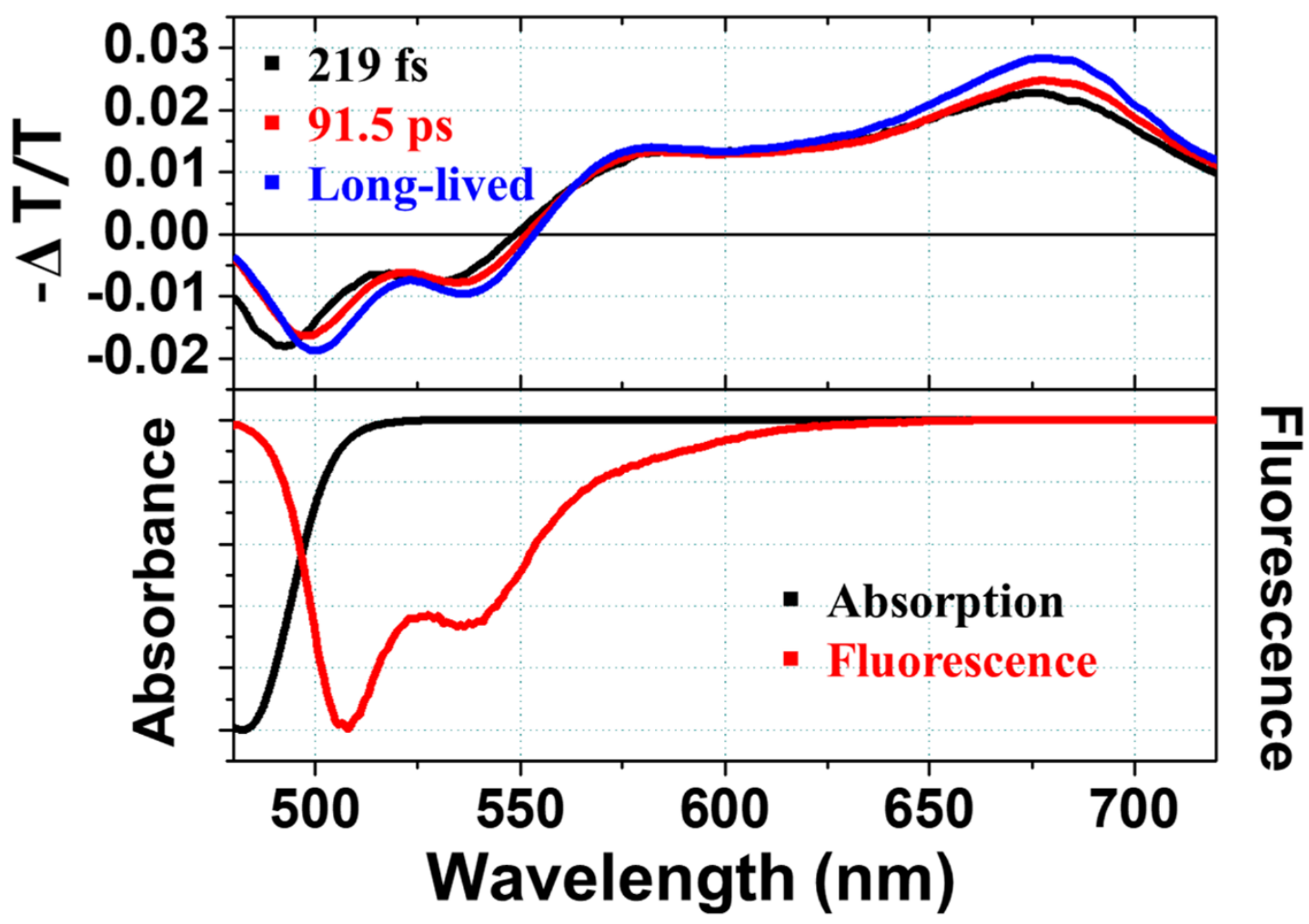

Figure S5. The comparison of peak positions between a steady-state fluorescence spectrum and stimulated emission bands of the $3^{\text {rd }}$ SADS in CHX. 

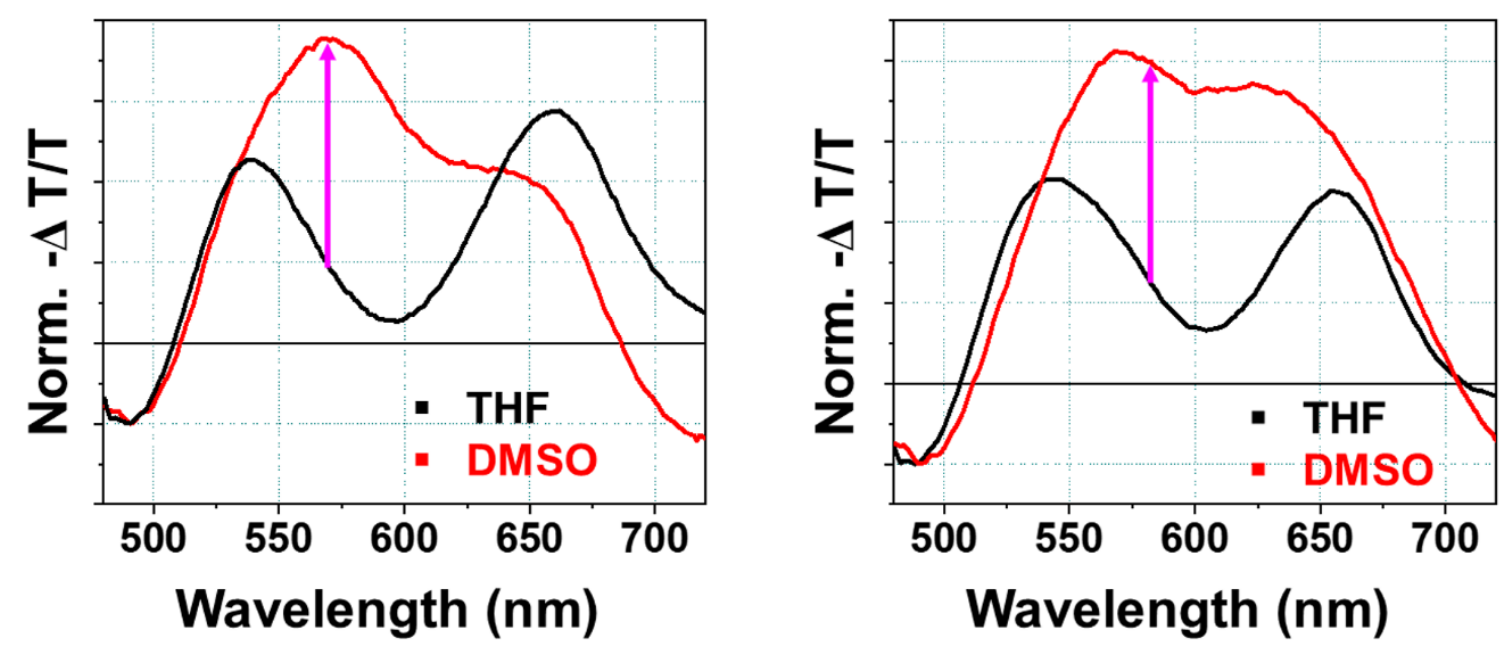

Figure S6. Normalized SADSs divided by GSB for each solvent: THF (black) and DMSO (red) for (a) the $3^{\text {rd }} \mathrm{SADS}$ and (b) the $4^{\text {th }} \mathrm{SADS}$. After the $3^{\text {rd }} \mathrm{SADS}$, the growth of ESA is more significant in DMSO, compared with that in THF. 

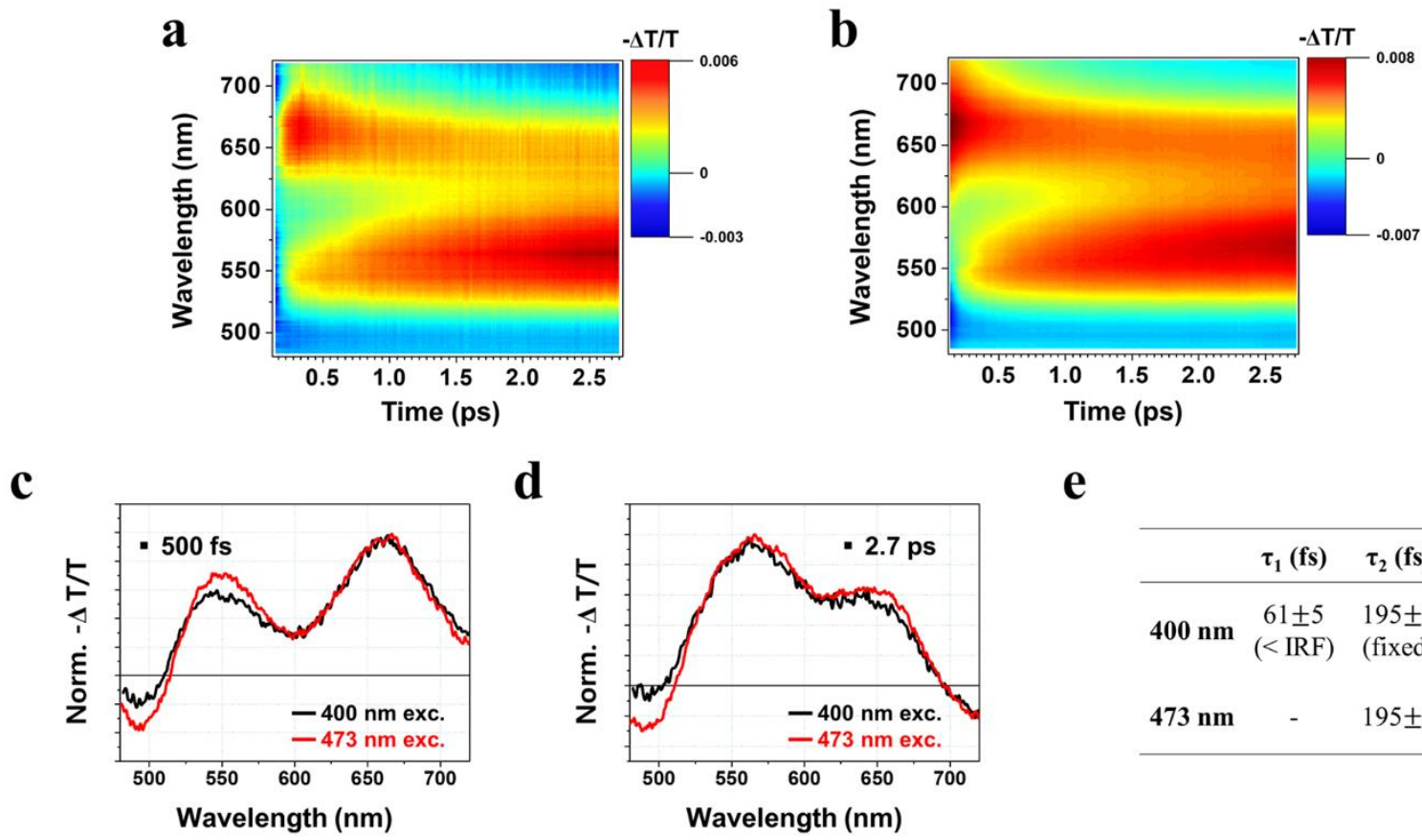

e

\begin{tabular}{cccc}
\hline & $\boldsymbol{\tau}_{\mathbf{1}}(\mathbf{f s})$ & $\boldsymbol{\tau}_{\mathbf{2}}(\mathbf{f s})$ & $\boldsymbol{\tau}_{\mathbf{3}}(\mathbf{p s})$ \\
\hline $400 \mathbf{n m}$ & $\begin{array}{c}61 \pm 5 \\
(<\mathrm{IRF})\end{array}$ & $\begin{array}{c}195 \pm 5 \\
(\text { fixed) }\end{array}$ & $\begin{array}{c}1.51 \pm 0.40 \\
(\text { fixed })\end{array}$ \\
$473 \mathbf{~ n m}$ & - & $195 \pm 5$ & $1.51 \pm 0.40$
\end{tabular}

Figure S7. Comparison of the ICT dynamics with excitation-wavelength dependence of DND in DMSO measured up to $\sim 3$ ps (a) after $400 \mathrm{~nm}$ excitation, which is nearly resonant to the $\mathrm{S}_{0} \rightarrow \mathrm{S}_{2}$ transition and (b) after $473 \mathrm{~nm}$ excitation, which is assigned to the $\mathrm{S}_{0} \rightarrow \mathrm{S}_{1}$ transition based on the TDDFT calculations. The TA spectra upon $400 \mathrm{~nm}$ excitation (black) and $473 \mathrm{~nm}$ excitation (red) are shown together at the time delays of (d) 500 fs and (e) 2.7 ps for comparison. The kinetic components measured up to $\sim 3$ ps are summarized in (e). An additional time constant within IRF is observed upon $400 \mathrm{~nm}$ excitation and it is attributable to the internal conversion (IC) from $S_{2}$ to $S_{1}$. However, the overall excited-state dynamics except for internal conversion and transient spectral features upon $400 \mathrm{~nm}$ excitation is similar to that upon $473 \mathrm{~nm}$ excitation at the ultrafast time scale regardless of excitation wavelengths. 
$\mathbf{a}$

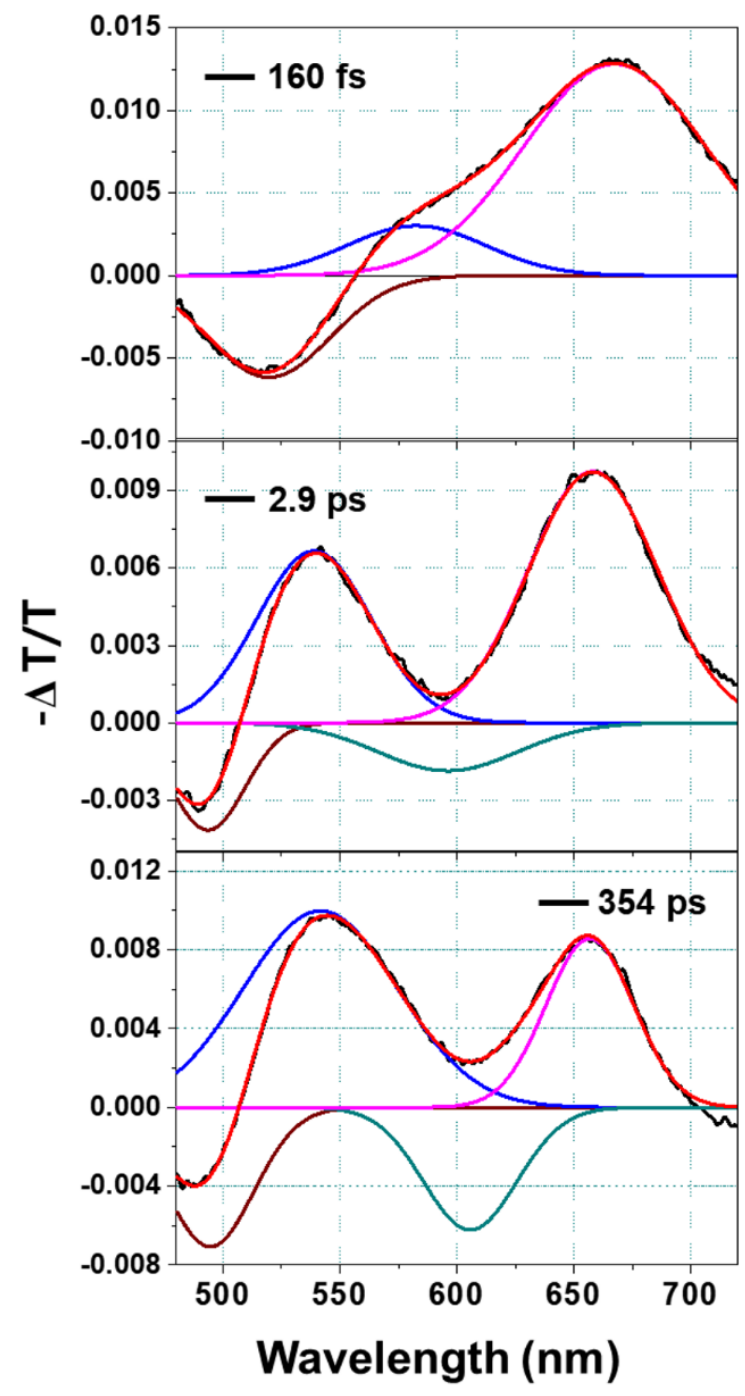

b

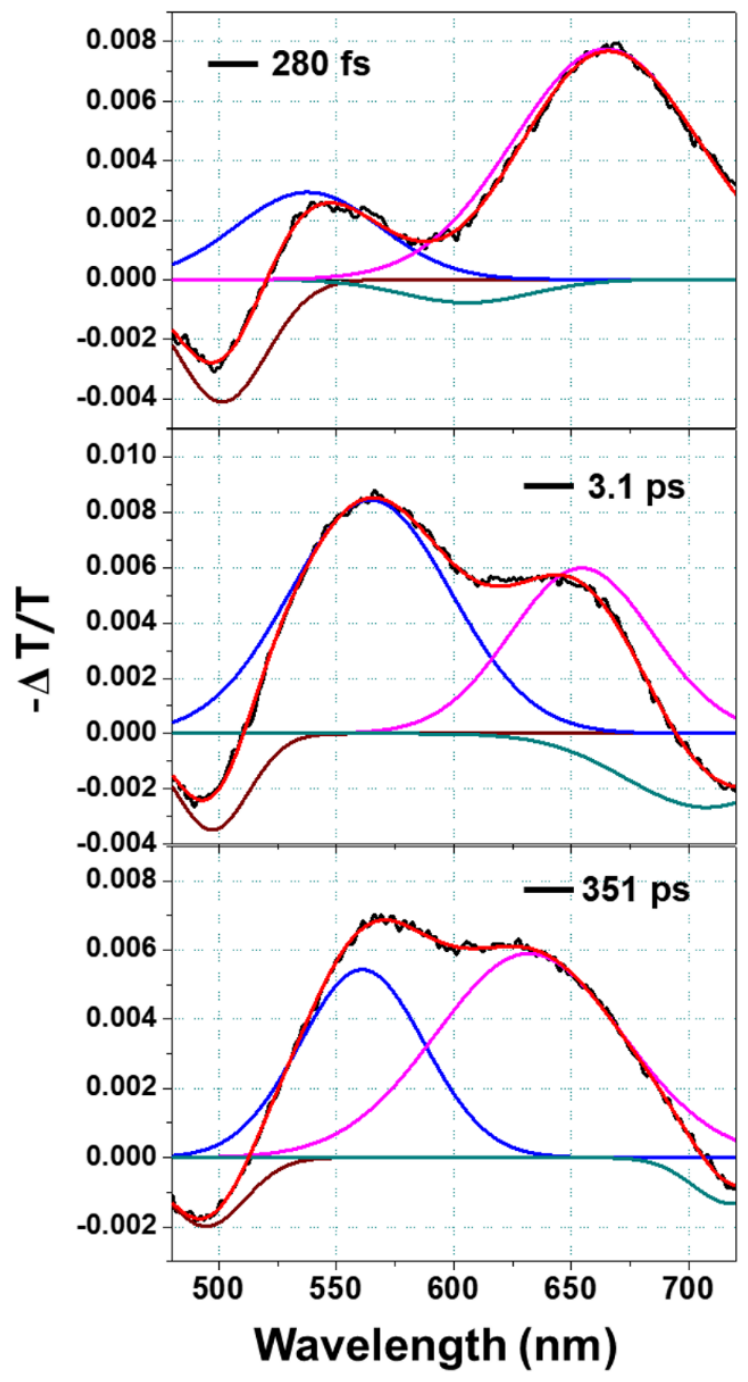

Figure S8. The examples of spectral fitting of transient absorption spectra using the sum of Gaussian functions. The selected TA spectra (black lines) and fits (red lines) of DND in (a) THF and (b) DMSO at specific time delays are shown together with individual Gaussian functions. 


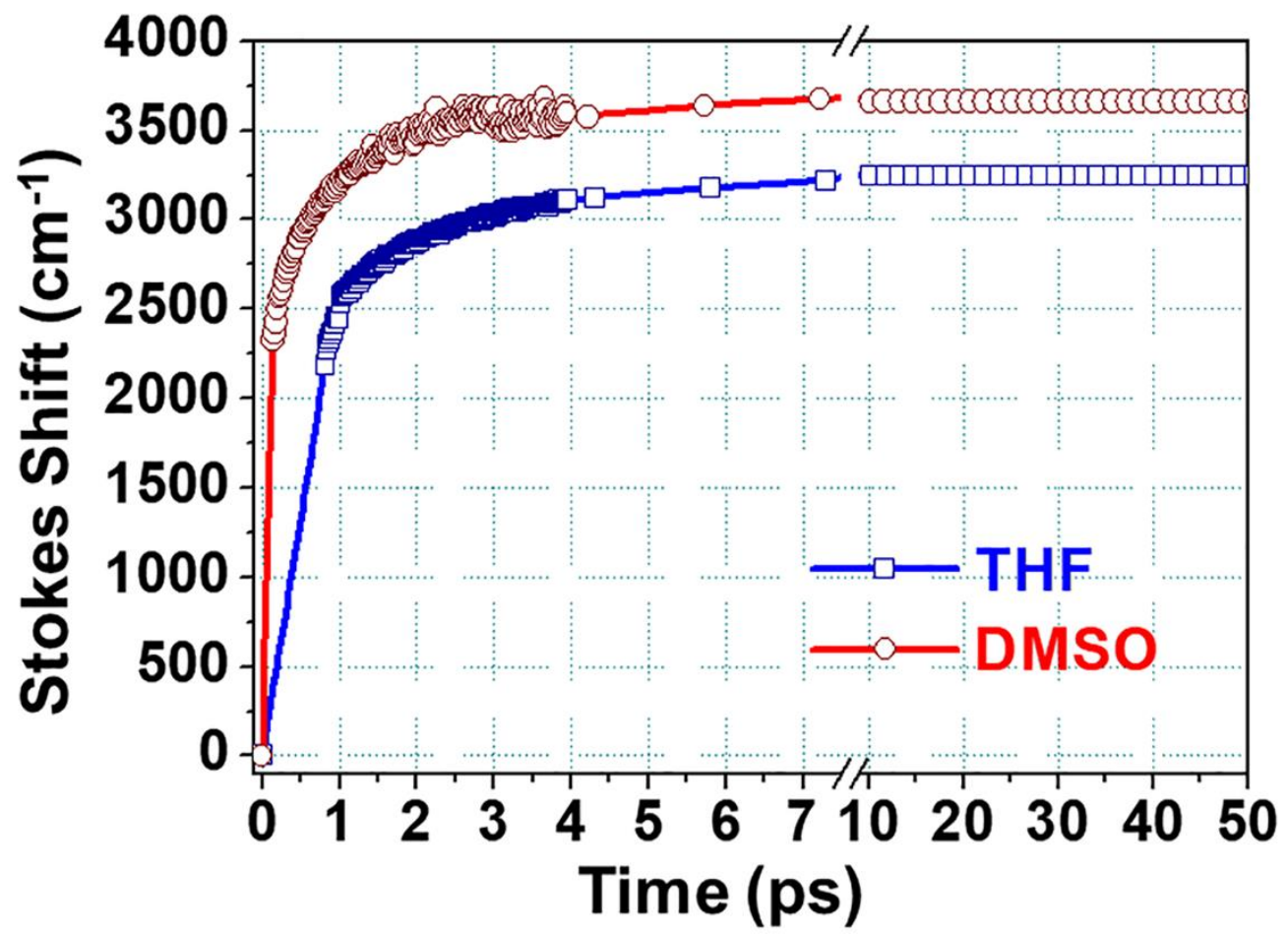

Figure S9. Time evolution of Stokes shift of SE peaks of DND in DMSO (red) and THF (blue). 
a

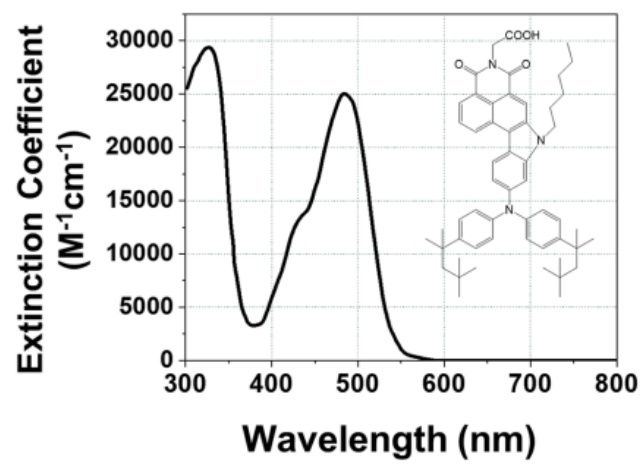

c

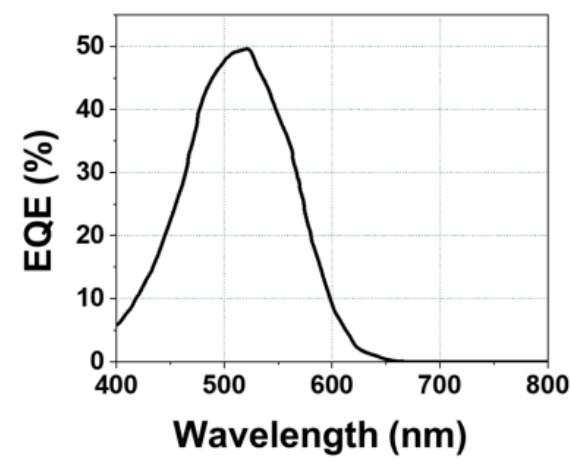

b

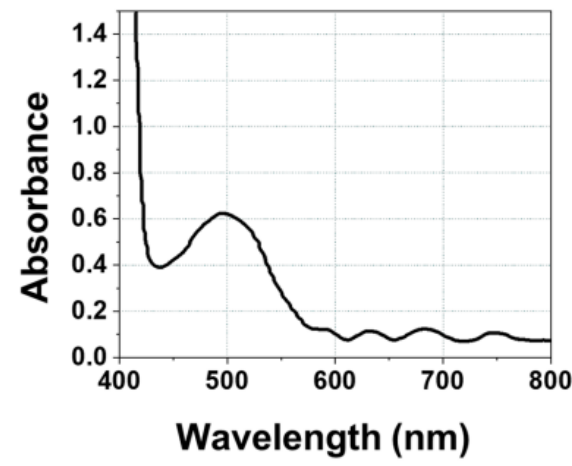

d

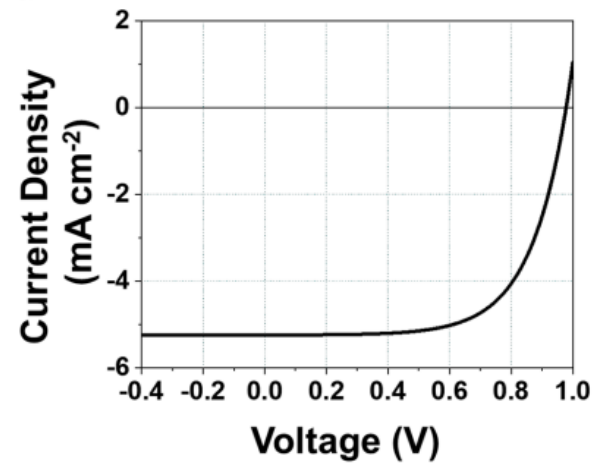

Figure S10. (a) Absorption spectrum of DND-1 in THF. Inset: Molecular structure of DND-1 (b) Absorption spectrum of DND-1 attached to the $\mathrm{TiO}_{2}$ electrode. (c) Wavelength-resolved EQE spectrum and (d) I-V characteristics of a photovoltaic cell using DND measured under an irradiance of $100 \mathrm{~mW} \mathrm{~cm}{ }^{-2}$, simulated AM $1.5 \mathrm{G}$ sunlight. 


\section{Supplementary Note 6. Cartesian coordinates of optimized geometries of DND}

The Cartesian coordinates of optimized geometries of DND in the ground state and $\mathrm{S}_{1}$ state are listed in Table S7 and Table S8, respectively.

Table S7. Ground-state optimized Cartesian coordinates $(\AA)$ of DND using MN15/6-311++G(d,p) with the IEFPCM method (in DMSO) level of theory.

\begin{tabular}{|c|c|c|c|}
\hline Atom & $\mathbf{X}$ & $\mathbf{y}$ & $\mathbf{Z}$ \\
\hline $\mathrm{C}(1)$ & -8.351 & -4.375 & 1.207 \\
\hline$C(2)$ & -7.147 & 5.235 & -0.675 \\
\hline$C(3)$ & -2.945 & -1.418 & -0.692 \\
\hline$C(4)$ & -3.461 & -0.197 & -0.188 \\
\hline$C(5)$ & -1.588 & -1.651 & -0.774 \\
\hline$C(6)$ & 1.717 & -2.672 & -1.165 \\
\hline$C(7)$ & 1.851 & -1.372 & -0.624 \\
\hline $\mathrm{C}(8)$ & 0.752 & -0.523 & -0.296 \\
\hline $\mathrm{C}(9)$ & -0.680 & -0.655 & -0.367 \\
\hline$C(10)$ & -1.217 & 0.565 & 0.117 \\
\hline $\mathrm{C}(11)$ & -2.587 & 0.806 & 0.224 \\
\hline$C(12)$ & 1.006 & 0.762 & 0.227 \\
\hline$C(13)$ & 3.166 & -0.877 & -0.392 \\
\hline$C(14)$ & 3.370 & 0.422 & 0.145 \\
\hline
\end{tabular}




\begin{tabular}{|c|c|c|c|}
\hline$C(15)$ & 2.303 & 1.240 & 0.453 \\
\hline$C(16)$ & 4.283 & -1.684 & -0.703 \\
\hline$C(17)$ & 4.115 & -2.948 & -1.232 \\
\hline $\mathrm{C}(18)$ & 2.821 & -3.442 & -1.463 \\
\hline$C(19)$ & 5.658 & -1.187 & -0.469 \\
\hline$C(20)$ & 4.732 & 0.930 & 0.390 \\
\hline $\mathrm{N}(21)$ & 5.804 & 0.074 & 0.107 \\
\hline $\mathrm{N}(22)$ & -4.854 & -0.009 & -0.122 \\
\hline $\mathrm{O}(23)$ & 6.641 & -1.853 & -0.764 \\
\hline $\mathrm{O}(24)$ & 4.930 & 2.056 & 0.828 \\
\hline$C(25)$ & 7.169 & 0.575 & 0.383 \\
\hline$C(26)$ & 7.930 & 0.909 & -0.911 \\
\hline $\mathrm{C}(27)$ & 7.999 & -0.321 & 1.301 \\
\hline $\mathrm{C}(28)$ & 9.178 & 0.513 & 1.830 \\
\hline $\mathrm{C}(29)$ & 9.442 & 0.928 & -0.643 \\
\hline$C(30)$ & 9.713 & 1.482 & 0.755 \\
\hline$C(31)$ & -0.375 & 2.738 & 1.017 \\
\hline $\mathrm{C}(32)$ & -7.441 & -3.222 & 0.875 \\
\hline $\mathrm{C}(33)$ & -7.788 & -2.289 & -0.108 \\
\hline$C(34)$ & -6.214 & -3.059 & 1.523 \\
\hline
\end{tabular}




\begin{tabular}{|c|c|c|c|}
\hline$C(35)$ & -5.361 & -2.006 & 1.207 \\
\hline$C(36)$ & -6.936 & -1.244 & -0.446 \\
\hline$C(37)$ & -5.711 & -1.092 & 0.210 \\
\hline$C(38)$ & -6.532 & 3.870 & -0.514 \\
\hline C(39) & -5.555 & 3.411 & -1.405 \\
\hline$C(40)$ & -6.931 & 3.012 & 0.513 \\
\hline$C(41)$ & -6.378 & 1.742 & 0.653 \\
\hline $\mathrm{C}(42)$ & -5.008 & 2.139 & -1.286 \\
\hline$C(43)$ & -5.413 & 1.292 & -0.249 \\
\hline $\mathrm{N}(44)$ & -0.190 & 1.412 & 0.461 \\
\hline $\mathrm{H}(45)$ & -8.192 & -4.720 & 2.230 \\
\hline $\mathrm{H}(46)$ & -9.400 & -4.096 & 1.096 \\
\hline $\mathrm{H}(47)$ & -8.166 & -5.224 & 0.542 \\
\hline $\mathrm{H}(48)$ & -7.559 & 5.595 & 0.269 \\
\hline H(49) & -6.413 & 5.960 & -1.030 \\
\hline $\mathrm{H}(50)$ & -7.963 & 5.213 & -1.404 \\
\hline $\mathrm{H}(51)$ & -3.643 & -2.179 & -1.021 \\
\hline $\mathrm{H}(52)$ & -1.251 & -2.601 & -1.168 \\
\hline $\mathrm{H}(53)$ & 0.729 & -3.072 & -1.353 \\
\hline $\mathrm{H}(54)$ & -2.966 & 1.740 & 0.622 \\
\hline
\end{tabular}




\begin{tabular}{|c|c|c|c|}
\hline $\mathrm{H}(55)$ & 2.496 & 2.224 & 0.863 \\
\hline $\mathrm{H}(56)$ & 4.990 & -3.543 & -1.462 \\
\hline $\mathrm{H}(57)$ & 2.690 & -4.434 & -1.877 \\
\hline $\mathrm{H}(58)$ & 7.599 & 1.890 & -1.268 \\
\hline $\mathrm{H}(59)$ & 7.384 & -0.691 & 2.127 \\
\hline $\mathrm{H}(60)$ & 8.866 & 1.080 & 2.713 \\
\hline $\mathrm{H}(61)$ & 9.845 & -0.089 & -0.709 \\
\hline $\mathrm{H}(62)$ & 10.780 & 1.664 & 0.907 \\
\hline $\mathrm{H}(63)$ & -0.750 & 2.686 & 2.041 \\
\hline $\mathrm{H}(64)$ & -1.082 & 3.301 & 0.405 \\
\hline $\mathrm{H}(65)$ & 0.573 & 3.271 & 1.017 \\
\hline $\mathrm{H}(66)$ & -8.738 & -2.389 & -0.624 \\
\hline $\mathrm{H}(67)$ & -5.927 & -3.759 & 2.302 \\
\hline $\mathrm{H}(68)$ & -4.419 & -1.887 & 1.732 \\
\hline$H(69)$ & -7.218 & -0.532 & -1.215 \\
\hline $\mathrm{H}(70)$ & -5.226 & 4.057 & -2.213 \\
\hline $\mathrm{H}(71)$ & -7.680 & 3.347 & 1.225 \\
\hline $\mathrm{H}(72)$ & -6.694 & 1.092 & 1.462 \\
\hline $\mathrm{H}(73)$ & -4.258 & 1.795 & -1.990 \\
\hline $\mathrm{H}(74)$ & 6.998 & 1.504 & 0.929 \\
\hline
\end{tabular}




\begin{tabular}{lccc}
$\mathrm{H}(75)$ & 7.691 & 0.176 & -1.684 \\
$\mathrm{H}(76)$ & 9.951 & 1.519 & -1.409 \\
$\mathrm{H}(77)$ & 9.217 & 2.456 & 0.845 \\
$\mathrm{H}(78)$ & 8.362 & -1.188 & 0.750 \\
$\mathrm{H}(79)$ & 9.975 & -0.162 & 2.153 \\
\hline
\end{tabular}

Table S8. $\mathrm{S}_{1}$-optimized Cartesian coordinates $(\AA)$ of DND using TD-MN15/6-311++G(d,p) with the IEFPCM method (in DMSO) level of theory.

\begin{tabular}{|c|c|c|c|}
\hline Atom & $\mathbf{x}$ & $\mathbf{y}$ & $\mathbf{z}$ \\
\hline $\mathrm{C}(1)$ & -8.285 & -4.425 & 1.096 \\
\hline $\mathrm{C}(2)$ & -7.175 & 5.180 & -0.699 \\
\hline $\mathrm{C}(3)$ & -2.935 & -1.419 & -0.619 \\
\hline $\mathrm{C}(4)$ & -3.453 & -0.185 & -0.145 \\
\hline $\mathrm{C}(5)$ & -1.580 & -1.632 & -0.726 \\
\hline$C(6)$ & 1.682 & -2.650 & -1.127 \\
\hline $\mathrm{C}(7)$ & 1.831 & -1.358 & -0.613 \\
\hline$C(8)$ & 0.733 & -0.478 & -0.295 \\
\hline
\end{tabular}




\begin{tabular}{|c|c|c|c|}
\hline $\mathrm{C}(9)$ & -0.669 & -0.607 & -0.352 \\
\hline$C(10)$ & -1.222 & 0.638 & 0.111 \\
\hline $\mathrm{C}(11)$ & -2.573 & 0.865 & 0.224 \\
\hline $\mathrm{C}(12)$ & 1.007 & 0.840 & 0.208 \\
\hline $\mathrm{C}(13)$ & 3.155 & -0.858 & -0.383 \\
\hline $\mathrm{C}(14)$ & 3.363 & 0.452 & 0.130 \\
\hline$C(15)$ & 2.287 & 1.316 & 0.427 \\
\hline$C(16)$ & 4.265 & -1.683 & -0.675 \\
\hline $\mathrm{C}(17)$ & 4.076 & -2.977 & -1.191 \\
\hline $\mathrm{C}(18)$ & 2.798 & -3.452 & -1.413 \\
\hline$C(19)$ & 5.625 & -1.208 & -0.451 \\
\hline$C(20)$ & 4.712 & 0.940 & 0.365 \\
\hline $\mathrm{N}(21)$ & 5.775 & 0.070 & 0.089 \\
\hline $\mathrm{N}(22)$ & -4.821 & -0.002 & -0.034 \\
\hline $\mathrm{O}(23)$ & 6.620 & -1.893 & -0.718 \\
\hline $\mathrm{O}(24)$ & 4.927 & 2.082 & 0.797 \\
\hline
\end{tabular}




\begin{tabular}{|c|c|c|c|}
\hline$C(25)$ & 7.140 & 0.566 & 0.357 \\
\hline$C(26)$ & 7.920 & 0.838 & -0.942 \\
\hline$C(27)$ & 7.951 & -0.299 & 1.321 \\
\hline $\mathrm{C}(28)$ & 9.142 & 0.537 & 1.822 \\
\hline$C(29)$ & 9.429 & 0.834 & -0.666 \\
\hline$C(30)$ & 9.704 & 1.445 & 0.708 \\
\hline $\mathrm{C}(31)$ & -0.341 & 2.832 & 0.956 \\
\hline$C(32)$ & -7.386 & -3.255 & 0.811 \\
\hline$C(33)$ & -7.728 & -2.301 & -0.154 \\
\hline$C(34)$ & -6.173 & -3.099 & 1.494 \\
\hline$C(35)$ & -5.325 & -2.037 & 1.221 \\
\hline$C(36)$ & -6.889 & -1.233 & -0.442 \\
\hline$C(37)$ & -5.678 & -1.099 & 0.244 \\
\hline $\mathrm{C}(38)$ & -6.541 & 3.829 & -0.516 \\
\hline$C(39)$ & -5.521 & 3.389 & -1.366 \\
\hline$C(40)$ & -6.976 & 2.966 & 0.499 \\
\hline
\end{tabular}




\begin{tabular}{|c|c|c|c|}
\hline$C(41)$ & -6.418 & 1.708 & 0.663 \\
\hline $\mathrm{C}(42)$ & -4.953 & 2.130 & -1.218 \\
\hline$C(43)$ & -5.397 & 1.284 & -0.197 \\
\hline $\mathrm{N}(44)$ & -0.188 & 1.493 & 0.426 \\
\hline $\mathrm{H}(45)$ & -8.244 & -4.706 & 2.150 \\
\hline $\mathrm{H}(46)$ & -9.320 & -4.202 & 0.833 \\
\hline $\mathrm{H}(47)$ & -7.976 & -5.298 & 0.513 \\
\hline $\mathrm{H}(48)$ & -7.411 & 5.637 & 0.263 \\
\hline $\mathrm{H}(49)$ & -6.518 & 5.853 & -1.253 \\
\hline $\mathrm{H}(50)$ & -8.111 & 5.094 & -1.258 \\
\hline $\mathrm{H}(51)$ & -3.630 & -2.190 & -0.927 \\
\hline $\mathrm{H}(52)$ & -1.235 & -2.580 & -1.113 \\
\hline $\mathrm{H}(53)$ & 0.694 & -3.048 & -1.314 \\
\hline $\mathrm{H}(54)$ & -2.967 & 1.790 & 0.624 \\
\hline $\mathrm{H}(55)$ & 2.490 & 2.301 & 0.824 \\
\hline $\mathrm{H}(56)$ & 4.949 & -3.581 & -1.406 \\
\hline
\end{tabular}




\begin{tabular}{|c|c|c|c|}
\hline $\mathrm{H}(57)$ & 2.648 & -4.449 & -1.811 \\
\hline $\mathrm{H}(58)$ & 7.614 & 1.815 & -1.335 \\
\hline $\mathrm{H}(59)$ & 7.324 & -0.619 & 2.158 \\
\hline $\mathrm{H}(60)$ & 8.834 & 1.150 & 2.674 \\
\hline $\mathrm{H}(61)$ & 9.808 & -0.195 & -0.683 \\
\hline $\mathrm{H}(62)$ & 10.773 & 1.612 & 0.860 \\
\hline $\mathrm{H}(63)$ & -0.464 & 2.823 & 2.042 \\
\hline $\mathrm{H}(64)$ & -1.211 & 3.308 & 0.501 \\
\hline $\mathrm{H}(65)$ & 0.537 & 3.425 & 0.701 \\
\hline $\mathrm{H}(66)$ & -8.664 & -2.402 & -0.693 \\
\hline $\mathrm{H}(67)$ & -5.900 & -3.815 & 2.262 \\
\hline $\mathrm{H}(68)$ & -4.398 & -1.912 & 1.769 \\
\hline $\mathrm{H}(69)$ & -7.160 & -0.504 & -1.198 \\
\hline $\mathrm{H}(70)$ & -5.175 & 4.038 & -2.163 \\
\hline $\mathrm{H}(71)$ & -7.757 & 3.294 & 1.176 \\
\hline $\mathrm{H}(72)$ & -6.752 & 1.053 & 1.460 \\
\hline
\end{tabular}




\begin{tabular}{lccc}
$\mathrm{H}(73)$ & -4.177 & 1.79 & -1.895 \\
$\mathrm{H}(74)$ & 6.976 & 1.520 & 0.860 \\
$\mathrm{H}(75)$ & 7.667 & 0.085 & -1.691 \\
$\mathrm{H}(76)$ & 9.958 & 1.377 & -1.453 \\
$\mathrm{H}(77)$ & 9.226 & 2.431 & 0.750 \\
$\mathrm{H}(78)$ & 8.300 & & 0.813 \\
$\mathrm{H}(79)$ & 9.924 & -1.198 & \\
& & -0.137 & 2.183 \\
\hline
\end{tabular}




\section{SI References}

1. Würth, C.; Grabolle, M.; Pauli, J.; Spieles, M.; Resch-Genger, U., Comparison of methods and achievable uncertainties for the relative and absolute measurement of photoluminescence quantum yields. Anal. Chem. 2011, 83 (9), 3431-3439.

2. Henry, E. R.; Hofrichter, J., Singular Value Decomposition - Application to Analysis of Experimental-Data. Method Enzymol 1992, 210, 129-192.

3. Ihee, H.; Rajagopal, S.; Srajer, V.; Pahl, R.; Anderson, S.; Schmidt, M.; Schotte, F.; Anfinrud,

P. A.; Wulff, M.; Moffat, K., Visualizing reaction pathways in photoactive yellow protein from nanoseconds to seconds. Proc. Natl. Acad. Sci. U. S. A. 2005, 102 (20), 7145-7150.

4. $\quad$ Oang, K. Y.; Kim, J. G.; Yang, C.; Kim, T. W.; Kim, Y.; Kim, K. H.; Kim, J.; Ihee, H., Conformational Substates of Myoglobin Intermediate Resolved by Picosecond X-ray Solution Scattering. J. Phys. Chem. Lett. 2014, 5 (5), 804-808.

5. $\quad$ Kim, T. W.; Yang, C.; Kim, Y.; Kim, J. G.; Kim, J.; Jung, Y. O.; Jun, S.; Lee, S. J.; Park, S.; Kosheleva, I.; Henning, R.; van Thore, J. J.; Ihee, H., Combined probes of X-ray scattering and optical spectroscopy reveal how global conformational change is temporally and spatially linked to local structural perturbation in photoactive yellow protein. Phys. Chem. Chem. Phys. 2016, 18 (13), 8911-8919. 6. van Stokkum, I. H.; Larsen, D. S.; van Grondelle, R., Global and target analysis of time-resolved spectra. Biochimica et biophysica acta 2004, 1657 (2-3), 82-104.

7. Rolczynski, B. S.; Szarko, J. M.; Son, H. J.; Liang, Y. Y.; Yu, L. P.; Chen, L. X., Ultrafast Intramolecular Exciton Splitting Dynamics in Isolated Low-Band-Gap Polymers and Their Implication in Photovoltaic Materials Design. J. Am. Chem. Soc. 2012, 134 (9), $4142-4152$.

8. Roy, P.; Jha, A.; Yasarapudi, V. B.; Ram, T.; Puttaraju, B.; Patil, S.; Dasgupta, J., Ultrafast bridge planarization in donor-pi-acceptor copolymers drives intramolecular charge transfer. Nat. Commun. 2017, 8 . 